\title{
Range-wide Status Assessment of Howellia aquatilis (water howellia)
}

\author{
Prepared for:
}

U.S. Fish and Wildlife Service

By:

Scott Mincemoyer

Montana Natural Heritage Program

Natural Resource Information System

Montana State Library

July 2005

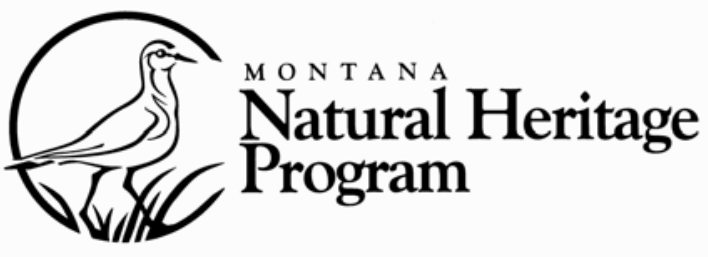




\section{Range-wide Status Assessment of Howellia aquatilis (water howellia)}

Prepared for:

U.S. Fish and Wildlife Service

Grant Agreement:

E-5-R-15

By:

Scott Mincemoyer
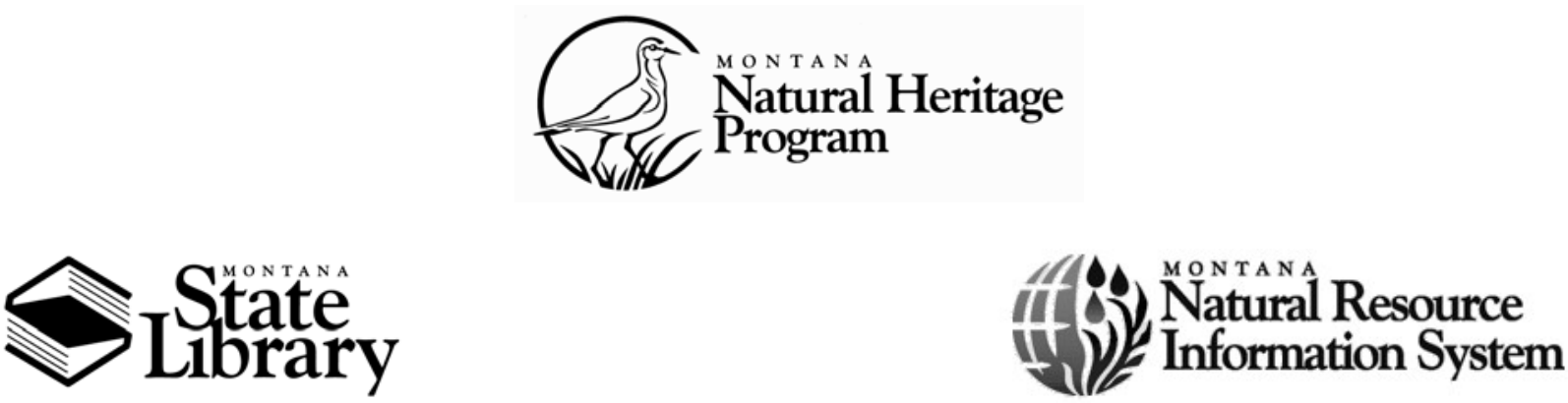

(c) 2005 Montana Natural Heritage Program

P.O. Box 201800 • 1515 East Sixth Avenue • Helena, MT 59620-1800 • 406-444-5354 
This document should be cited as follows:

Mincemoyer, S. 2005. Range-wide status assessment of Howellia aquatilis (water howellia). Report to the U.S. Fish and Wildlife Service. Montana Natural Heritage Program, Helena, MT. 21 pp. + appendices. 


\section{EXECUTIVE SUMMARY}

Howellia aquatilis A. Gray (water howellia) is an annual, aquatic plant endemic to the Pacific Northwest region of the United States. Listed as a threatened species under the Endangered Species Act in 1994, its current known distribution includes the states of California, Idaho, Montana, Oregon and Washington. At the time of federal listing under the ESA it was known from 107 occurrences in three states. Today, 214 presumed extant occurrences are known, occupying approximately 285 acres. The majority of occurrences are concentrated in three metapopulations in the Swan Valley of west-central Montana, Spokane County, Washington and in western Washington, mainly on Fort Lewis Military Reservation.

The federal government manages lands partially or entirely encompassing $82 \%$ of extant occurrences, with one agency, the U.S. Forest Service, managing $57 \%$ of known occurrences. The U.S. Fish and Wildlife Service manages lands with 35 occurrences and the U.S. Department of Defense has 17 occurrences. In Montana, "checkerboard" land ownership in the Swan Valley complicates management with many occurrences occupying more than one ownership.

Primary threats to water howellia are from changing water levels and invasive species. Consecutive years of drought or exceedingly wet years may negatively affect populations if ponds remain dry or if they do not dry out enough to allow germination in the fall. Monitoring data has shown that populations have the ability to rebound following consecutive years of unfavorable conditions, though seed viability and germination rates are significantly reduced.

Invasive species pose a serious and long-term threat to water howellia. Introduced genotypes of Phalaris arundinacea (reed canary grass) and Iris pseudacorus (yellow flag iris) are two of the largest threats to date. P. arundinacea is a potential threat to water howellia range-wide. In contrast, I. pseudacorus has been a problem in water howellia ponds mainly in western
Washington. Additional aquatic and riparian invasive species also pose threats on a more limited scale, though several have the potential to more severely impact water howellia in the future.

Monitoring programs have been implemented on the Flathead National Forest, Montana, Fort Lewis, Washington and for the Idaho population, with several years of data now available for these populations. Additional monitoring programs still need to be implemented for other populations.

Total population numbers for Howellia aquatilis, as with any annual species, are difficult to estimate without quantitative survey data over many years. Approximately $1 / 4$ of the known populations have only been visited once, and in many cases only presence/absence data is available due to the difficulty of collecting accurate and precise quantitative data for the aquatic species. If the sum of the minimum and maximum number of plants estimated at each occurrence are used as a basis for the species total population, a range of 18,000-138,000 plants is derived. A sum of the median population size for each occurrence results in a figure of approximately 51,000 plants.

The annual nature of the species in conjunction with its narrow ecological niche makes it vulnerable to long-term unfavorable weather patterns and climate change. In addition, the clustering of populations in just a few geographic areas also makes it more susceptible to regional and local influences. Invasion of the species' habitat by non-native species is also a problem that most likely will continually need to be addressed. However, the majority of known populations occur on public lands providing the opportunity for the implementation of conservation measures and strategies beneficial to the long-term survival of the species. With implementation of management plans, continued monitoring and conservation protection of additional populations, delisting should be an achievable goal. 


\section{ACKNOWLEDGEMENTS}

This assessment was made possible by a grant from the U.S. Fish and Wildlife Service.

Numerous individuals and organizations provided monitoring and occurrence data, including but not limited to the California Natural Diversity Database, Idaho Conservation Data Center, Oregon Natural Heritage Program, Washington Natural Heritage Program, Flathead National Forest and the Land Condition Trend Analysis Program at Fort Lewis Military Reservation. Thanks to Henning Stabins for providing management information for Plum Creek Timber Company land in relation to water howellia and to Karen Gray for providing additional information on the Idaho population. Thanks to Kathy Lloyd and Kathy Martin for diligently updating the Montana Natural Heritage Program's database of Montana water howellia occurrences. Finally, thanks to several reviewers who provided valuable input and comments. 


\section{TABLE OF CONTENTS}

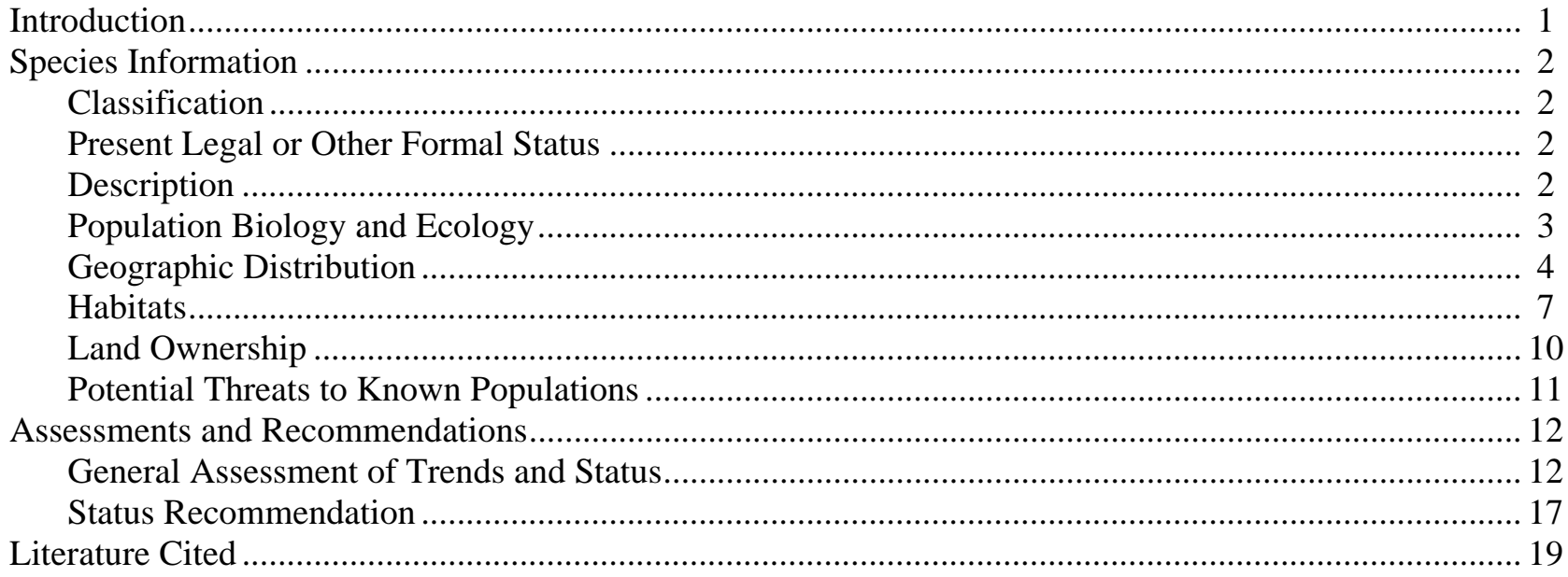

Appendix A. Howellia aquatilis Occurrence Data by State and Element Occurrence Number Appendix B. Annual Howellia aquatilis Survey Data by State and Element Occurrence Number Appendix C. Howellia aquatilis Bibliography

Appendix D. Global/State Rank Definitions

Appendix E. Element Occurrence Rank Definitions

\section{LIST OF FIGURES}

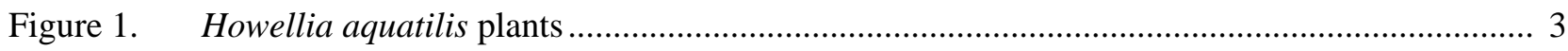

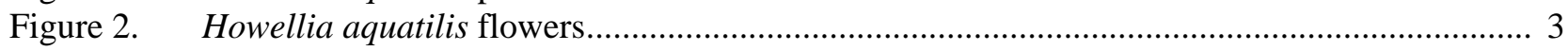

Figure 3. Distribution of Howellia aquatilis (extant and historical occurrences) ................................... 6

Figures 4-7. Howellia aquatilis habitats. ......................................................................................... 8

Figure 8. $\quad$ Idaho H. aqautils pond dominated by Phalaris arundinacea and Acorus calamus.................. 12

Figure 9. Relationship between number of $H$. aquatilis populations observed (sampled) and number of plants estimated each sample year. .................................................................................... 15

Figure 10. Sampling intensity of individual H. aquatilis occurrences stratified by state and number of

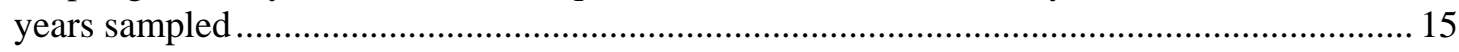

\section{LIST OF TABLES}

Table 1. Date of last observation of presumed extant occurrences of Howellia aquatilis by state and

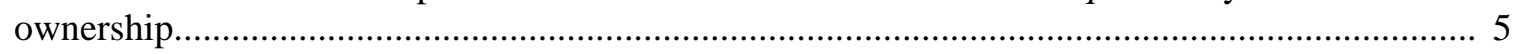

Table 2. Vascular plant species commonly associated with Howellia aquatilis sites by state.................... 9

Table 3. Number of known Howellia aquatilis occurrences by year......................................................... 13

Table 4. Ranking factors and assigned scores for the $H$. aquatilis global status assessment....................... 16 


\section{INTRODUCTION}

Howellia aquatilis A. Gray (water howellia) is an annual, aquatic plant endemic to the Pacific Northwest region of the United States. Listed as a threatened species under the Endangered Species Act in 1994, its current known distribution includes the states of California, Idaho, Montana, Oregon and Washington. Its biology and ecology make it vulnerable to short and long-term changes in climate and weather patterns as well as anthropogenic threats.

Thorough status reviews for the species are out of date with the most recent ones being completed by Roe and Shelly (1992) and the U.S. Fish and Wildlife Service (1994). In addition, a draft recovery plan was prepared for the species in 1996 but never finalized and adopted by the U.S. Fish and Service (USFWS 1996). In 1994, a conservation strategy for the species was finalized by Region 1 of the U.S. Forest Service covering all national forest lands in Montana.

The purpose of this assessment is to compile and analyze current data on the known distribution, population ecology and management status of Howellia aquatilis. In particular, population trends and current threats to the species are of particular importance in determining its current range-wide status and whether a change in listing status may be warranted. 


\section{SPECIES INFORMATION}

\section{A. Classification}

1. Scientific Name: Howellia aquatilis A. Gray

2. Common Name: water howellia

3. Family: Campanulaceae (harebell family)

4. Type Description and Specimens Cited: Gray, Asa. 1879. Proceedings of the American Academy of Arts and Sciences. 15:43-44.

Thomas \& Joseph Howell 137, 1879. Oregon, Sauvies Island (Holotype: GH). Probable Isotypes at NY.

Herbarium reference codes are from Holmgren and Holmgren (1990).

5. Size of Genus: Howellia is a monotypic genus.

\section{B. Present Legal or Other Formal Status}

\section{Global}

i. Legal Status: None.

ii. Heritage Rank: G3. (See Appendix D for Heritage Rank Definitions.)

\section{National}

a. Legal Status: Water howellia is endemic to the United States. The species was listed as threatened under the Endangered Species Act on July 14, 1994 (U.S. Fish and Wildlife Service 1994).

\section{State}

a. California

i. Legal Status: None.

ii. Heritage Rank: S1. b. Idaho

i. Legal Status: None.

ii. Heritage Rank: S1.

c. Montana

i. Legal Status: None.

ii. Heritage Rank: S2.

d. Oregon

i. Legal Status: None.

ii. Heritage Rank: S1.

e. Washington

i. Legal Status: None.

ii. Heritage Rank: S2S3.

\section{Description}

1. General Non-technical Description: Water howellia is a glabrous, much-branched, annual, aquatic herb with fragile, submerged and floating stems that are up to $100 \mathrm{~cm}$ tall. The simple, alternate or occasionally opposite or whorled stem leaves are narrowly linear, 1-5 cm long, and entiremargined. Beneath the surface of the water, small flowers that produce seeds without opening are solitary in the leaf axils. Once the stems reach the surface, small, white flowers are borne in a narrow, terminal, leafy-bracted inflorescence. The white corolla is $2-3 \mathrm{~mm}$ long. Flowering occurs on the surface of the water. The fruit, which forms below the attachment of the petals, is a capsule that is 1-2 $\mathrm{cm}$ long containing elongate seeds that are up to 2$4 \mathrm{~mm}$ long.

2. Technical Description: Flaccid annual, aquatic herb, mostly submergent, often with emergent branches; plants naked below, branched above; whole plant glabrous, green, about 10-60 $\mathrm{cm}$. tall, occasionally taller; leaves numerous, alternate, or some of them subopposite or whorled in threes, linear or linear-filiform, entire or nearly so, $1-5 \mathrm{~cm}$. long, up to $1.5 \mathrm{~mm}$ wide; flowers white, mostly 3-10, axillary, often scattered, 
pedicellate or subsessile, both petaliferous (when emergent), the fully-developed corollas about 2-2.7 $\mathrm{mm}$ long, irregular, with the tubes deeply cleft dorsally, and five-lobed; filaments and anthers connate, two of the anthers shorter than the others; calyx lobes 1.5-7 mm. long; stout pedicels 1-4 (8) $\mathrm{mm}$. long, merging gradually with the base of the capsule; ovary unilocular, with parietal placentation; stigma 2-lobed; fruit 5-13 mm. long, 1-2 mm. thick, irregularly dehiscent by the rupture of the very thin lateral walls; seeds large, 2-4 mm. long, 5 or fewer, shiny brown (Shelly 1988).

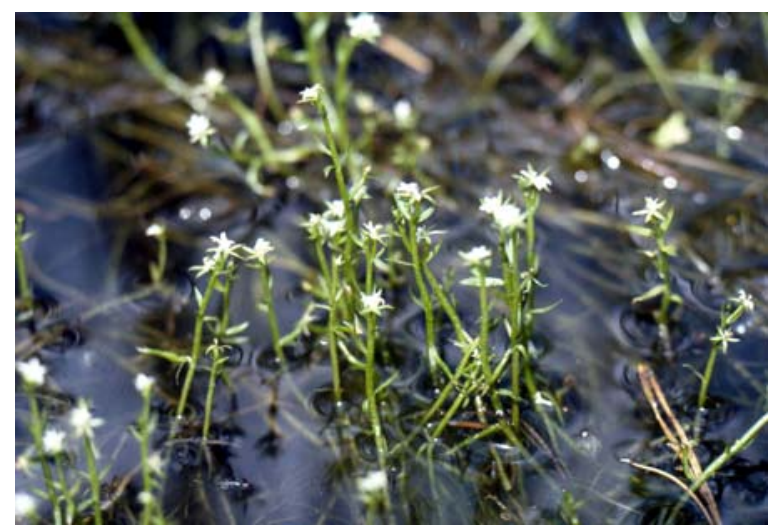

Figure 1. Howellia aquatilis plants

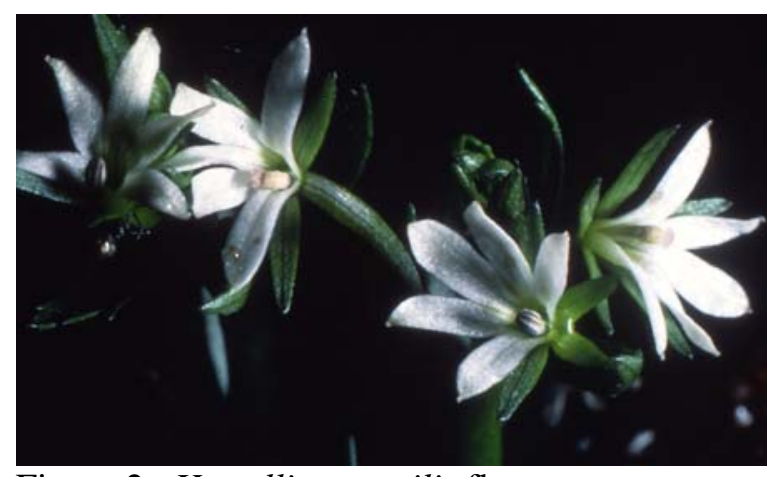

Figure 2. Howellia aquatilis flowers

3. Similar Species: Callitriche heterophylla (Callitrichaceae) is vegetatively similar to water howellia and found growing with it. However, the submergent linear leaves of the latter species are most often opposite and only rarely whorled. The floating leaves are broadly ovate in contrast to the linear leaves of water howellia. Additionally, the flowers are axillary and inconspicuous due to the lack of a corolla.

In California, Legenere limosa (Campanulaceae) occurs in similar habitats as water howellia and in the same geographic area. However, the branching pattern of $L$. limosa is different and the leaves are shorter and not as linear. In Montana, Downingia laeta, also in the Campanulaceae, occurs in shallow water and drying mud around ponds and lakes in the valleys and on the plains, though it is easily distinguished by its light blue to purplish flowers marked with white or yellow.

\section{Population Biology and Ecology}

1. Reproductive Biology and Phenology: Howellia aquatilis is an annual, reproducing entirely by seed. The plant is predominantly a winter annual with germination taking place in the fall and seedlings over-wintering and resuming growth in the spring. Germination of seeds occurs only when ponds dry out and seeds are exposed to air (Lesica 1990, 1992). Thus, the population size in a given year is affected by the extent to which the pond dries out at the end of the previous year. Due in part to this dependence, population size varies widely from year to year. Exceedingly wet years will detrimentally affect population size the next year since seeds will not germinate.

Conversely, very dry years may also adversely impact populations if enough water is not present to support a "good" population and subsequent production of seed. Long-term seed viability is uncertain though it has been shown that seeds lying in the soil longer than eight months have decreased rates of germination and vigor (Lesica 1992).

Thus, two or more consecutive years of exceedingly wet conditions or dry conditions may have a severe detrimental impact on population size due to the decreased number of viable seeds. Monitoring data from Montana populations have shown populations rebound after two consecutive years with no plants observed. This provides some evidence that a significant number of seeds remain viable for at least three years, providing a buffer against unfavorable growing conditions in consecutive years.

Water howellia produces both submerged, cleistogamous flowers (flowers that do not open and are self-pollinated) and emergent, chasmogamous flowers (flowers that open and allow for pollination). Studies by Lesica et al. (1988) and Shelly and Moseley (1988) report that 
self-pollination appears to be the common means of fertilization and that out-crossing, though possible, is probably extremely rare.

Plants begin growth in the spring. In low elevation populations in western Washington, this is typically early April and in western Washington and Montana by early May. Emergent flowers bloom soon after the stems reach the water surface and are present from June into August. Seed dispersal starts in June from submerged flowers and extends until late summer from emergent flowers (USFWS 1996). Spread of seeds by waterfowl or other animals between ponds, though possible, has not been documented.

2. Genetics: Original isozyme studies by Lesica et al. (1988) showed a very low level of genetic diversity within and among populations. Additional isozyme work by Brunsfeld and Baldwin (1998) included California populations, used the same 18 loci as Lesica (1988), and five additional loci, and also did not detect any variation within or among populations. However, limited chloroplast DNA sequence data and Random Amplified Polymorphic DNA (RAPD) analyses do show some variation among populations. The interpretation and expectations for genetic variation for Howellia aquatilis as summarized by Brunsfeld and Baldwin (1998) are, "The short generation time of the species should foster a rapid generation of genetic diversity and rate of evolution. On the other hand populations are known to fluctuate in size leading to periodic bottlenecks and genetic drift in unfavorable years.”

\section{E. Geographic Distribution}

1. Range: Howellia aquatilis is a Pacific Northwest endemic known from northern California, western Oregon, Washington, northern Idaho and western Montana. The first collection of the species was from western Oregon (Multnomah County), in a slough on Sauvies Island along the Columbia River near Portland in 1879.

Subsequent collections were made in Multnomah County in 1881, 1885 and 1886, Clackamas County in 1892 and Marion County in 1926. A California population was discovered in Mendocino County in 1928, an Idaho population in
1967, Montana in 1978 and Washington in 1937 (USFWS 1994, USFWS 1996, Shelly and Moseley 1998). At the time of listing under the Endangered Species Act, 107 total extant occurrences were known. These were found in Montana (59), Washington (47) and a single occurrence in Idaho (USFWS 1994). Populations in California and Oregon were believed to be extirpated. Today, there are 214 total occurrences known from five states: California (6), Idaho (1), Montana (138), Oregon (1) and Washington (68). The majority of the occurrences are in three metapopulations, one in the Swan Valley in western Montana, one in Spokane County in eastern Washington and the third in Pierce County in western Washington.

\section{California:}

In 1928, Alice Eastwood collected the plant near Howard Lake in Mendocino County. Surveys in 1979 and 1980 failed to relocate the plant.

However, the plant was again documented in the area in 1996 and it is currently known from six sites in Mendocino County (USFWS 1994, Isle 1997, California Natural Diversity Database 2005).

Idaho:

The first collection of water howellia from the state was reported in Kootenai County in 1892 near Spirit Lake. It is believed that the location information with this specimen is in error and surveys in the area have failed to locate any populations (Shelly 1988). One population, occupying 3 ponds, in Latah County was discovered in 1967 and has been monitored annually from 1999 to 2004 (Idaho Conservation Data Center 2005, Gray 2005). Extensive surveys during 1994 and several other years have failed to locate any additional occurrences (USFWS 1996).

\section{Montana:}

Bruce McCune made the first known collection of the species in the state in the Swan River Valley (Missoula County) in 1978 (McCune 1982). By 1986, only 13 total populations were documented. One year later an additional 39 occurrences were located in the general vicinity. This number remained fairly stable for seven years with only six additional populations discovered. In 1995 an additional 43 ponds were found to contain populations, bringing the total known occurrences to 101 in the state. Since 1995, populations have 
been discovered in an additional 37 ponds bringing the total number of documented occurrences to 138 in the Swan Valley. However, 45 of the populations have not been visited for more than five years and 27 occurrences have only been visited once (Montana Natural Heritage Program Database 2005).

\section{Oregon:}

As noted above, the first known collection of the species occurred in 1879 from Sauvies Island, Multnomah County. A subsequent collection from the Island was made in 1886. However, it has not been seen since then. Other historical collections occurred in 1892 in Clackamas County and in 1926 in Marion County. It was long presumed that water howellia was extirpated in the state until a rediscovery of the species in 2002 on the William Finley National Wildlife Refuge in Benton County in the west-central part of the state (USFWS 1996, USFWS 1994, Oregon Natural Heritage Program Database 2005).
Washington:

In 1937, two collections of water howellia were made on the west side of the Cascades, one in Thurston County and the other in Mason County (USFWS 1996). No other collections were made until 1978, when a population was discovered in eastern Washington near Spokane. An additional population was discovered in 1980 in Clark County across the Columbia River from the type locality. Many additional populations have been found since the 1980's in Spokane County and on McChord Air Force Base and Fort Lewis Military Reservation in Pierce County, bringing the total number of presumed extant occurrences in the state to 68 , including one new population discovered on Fort Lewis in 2004. Twenty-five of the Washington populations have not been visited for more than 10 years and 28 occurrences have only been visited once (USFWS 1996, Washington Natural Heritage Program Database 2005, Wolford 2004).

Table 1. Date of last observation of presumed extant occurrences of H. aquatilis by state and ownership.

\begin{tabular}{|c|c|c|c|c|c|c|}
\hline \multirow[t]{2}{*}{ State } & \multirow[t]{2}{*}{ Ownership } & \multirow{2}{*}{$\begin{array}{l}\text { Pop. Totals } \\
\text { by Ownership }\end{array}$} & \multicolumn{4}{|c|}{ Date of Last Observation (\# of Populations) } \\
\hline & & & 2000-2004 & 1995-1999 & 1990-1994 & pre-1990 \\
\hline California & USFS & 6 & 2 & 4 & & \\
\hline Idaho & Private* $^{*}$ & 1 & 1 & & & \\
\hline \multirow{10}{*}{ Montana } & $\begin{array}{l}\text { Plum Creek } \\
\text { Timber Company }\end{array}$ & 12 & 1 & 11 & & \\
\hline & Plum Creek/State & 1 & 1 & & & \\
\hline & $\begin{array}{l}\text { Plum } \\
\text { Creek/Private }\end{array}$ & 1 & & 1 & & \\
\hline & Private (Other) & 3 & & 2 & 1 & \\
\hline & State & 2 & 2 & & & \\
\hline & TNC & 1 & & 1 & & \\
\hline & USFS & 82 & 77 & 5 & & \\
\hline & $\begin{array}{l}\text { USFS/Plum } \\
\text { Creek }\end{array}$ & 19 & 10 & 9 & & \\
\hline & USFS/State & 1 & 1 & & & \\
\hline & $\begin{array}{l}\text { USFS/Other } \\
\text { Private }\end{array}$ & 16 & 1 & 12 & & 3 \\
\hline Oregon & USFWS & 1 & 1 & & & \\
\hline \multirow{5}{*}{ Washington } & BLM & 1 & & & 1 & \\
\hline & Private & 13 & & 2 & 1 & 10 \\
\hline & State & 3 & 1 & 2 & & \\
\hline & USDOD & 17 & 17 & & & \\
\hline & USFWS & 34 & & 21 & 13 & \\
\hline \multicolumn{2}{|l|}{ Totals: } & 214 & 115 & 70 & 16 & 13 \\
\hline
\end{tabular}

*Property willed to the National Audubon Society (Idaho Conservation Data Center Database 2005) 


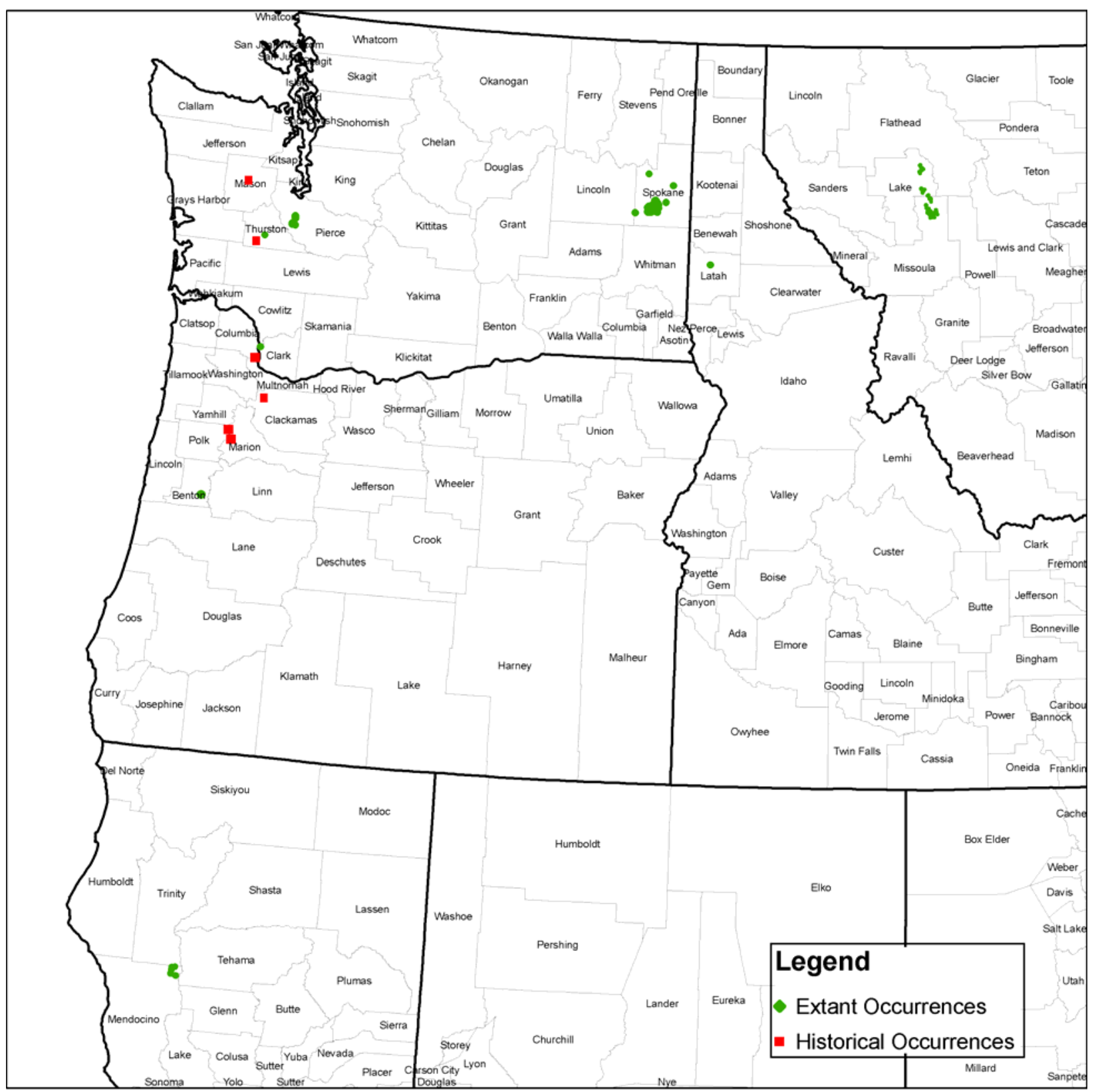

Figure 3. Distribution of Howellia aquatilis (Extant and Historical Occurrences)

\section{Historical Populations:}

Idaho:

Sandberg, J.H. 669. July 22, 1892. Reported from Kootenai County. Vicinity of Spirit Lake. Floating in subalpine lake.

It is believed that the location information associated with this collection may be in error.
Attempts to relocate populations in the area in 1988 failed to find any populations (USFWS 1996, Shelly and Moseley 1988).

Oregon:

Multnomah County, Sauvies Island (type locality). 1879. Last seen in 1886. However, a new population was discovered across the Columbia River in Clark County, Washington in 1980. 
- Thomas \& Joseph Howell 137

Clackamas County, Lake Oswego. 1892. Not seen since original collection.

- Howell s.n.

Marion County, near Painter's Woods and

Salem. 1926. Last seen in 1935.

- Thompson 4927, 4967

- J.C. Nelson 5075

- M.E. Peck 15935

Marion County, Mission Bottom, near Salem. 1977.

- Reported by W. Bluhm

The Marion and Clackamas County sites are in areas that have largely been developed (Shelly and Moseley 1988).

Washington:

Mason County, small lake about 20 miles north of Shelton. 1937. Last seen in 1937.

- W.J. Eyerdam 1211

Thurston County, roadside pond in or near Millersylvania State Park. 1937. Last seen in 1937 (USFWS 1996).

- J. Rudd s.n.

\section{Additional Survey Areas:}

Idaho:

Extensive searches in northern Idaho in June 1988 did not result in the discovery of any new populations (Shelly and Moseley 1988).

Montana:

437 ponds searched in Montana between 1987 and 1991 in Flathead, Lake and Missoula Counties (Roe and Shelly 1992, Schassberger and Shelly 1991, Shelly 1989).

\section{Oregon:}

Intensive surveys failed to relocate any occurrences near the historical collections (USFWS 1996).

4. Extant Sites: Howellia aquatilis occurrence data is provided in Appendices A and B.

\section{F. Habitats}

The dominant habitat for Howellia aquatilis is small, vernal, freshwater wetlands and ponds with an annual cycle of filling with water and drying up late in the season (Figures 4-7). These vernal ponds and wetlands usually fill with water over the fall, winter and early spring, but then at least partially dry up towards the end of the growing season. Depending on annual patterns of temperature and precipitation the drying of the pond may be complete or partial by the fall. These sites are usually shallow and less than one meter in depth, although water howellia is sometimes found in water up to two meters deep (USFWS 1996). Additionally, a few occurrences of water howellia are found in oxbow sloughs and surrounding marshy areas such as those on the Swan River Oxbow Preserve managed by The Nature Conservancy in Montana and the type locality in Oregon. Across its range, Howellia aquatilis occurs at elevations as low as three meters in Washington to 1372 meters in Montana.

Howellia aquatilis ponds are typically surrounded at least in part by forested vegetation. Tree species vary across the range of water howellia, though usually include some broadleaf deciduous trees. In Montana, Populus trichocarpa (black cottonwood) is commonly associated and to a lesser extent, Populus tremuloides (quaking aspen) and Betula papyrifera (paper birch). In eastern Washington, Populus tremuloides is an associate and Fraxinus latifolia (Oregon ash) is commonly associated with the populations in the western part of the state.

A variety of deciduous shrubs and herbaceous species are commonly associated with water howellia occurrences, two of the most common being Carex vesicaria (inflated sedge) and Phalaris arundinacea (reed canary grass). The latter species being probably of mainly introduced origin. Table 2 lists species commonly associated with water howellia occurrences by state. 
Figures 4-7. Howellia aquatilis habitats.

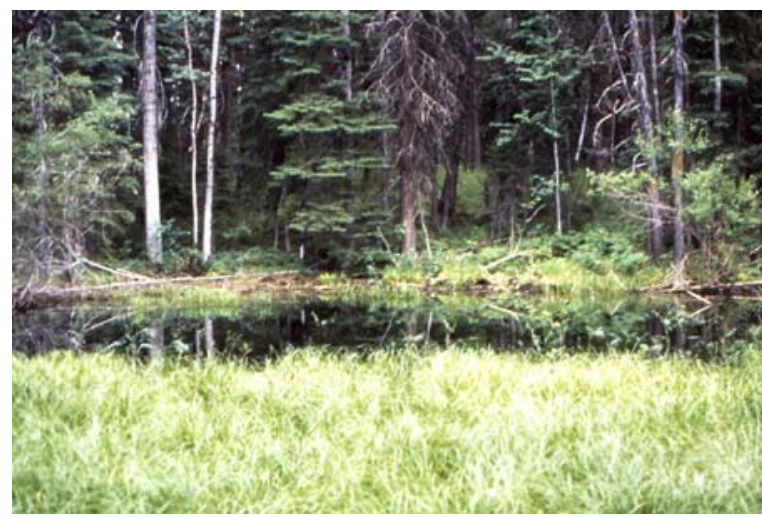

Figure 4. Condon Creek, Montana water howellia pond (unknown EO \#)

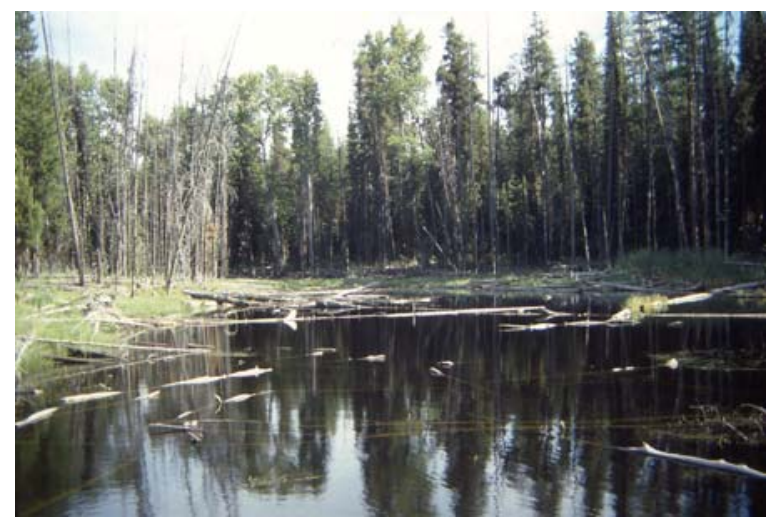

Figure 5. Lindbergh Lake, Montana water howellia pond (EO \#2)

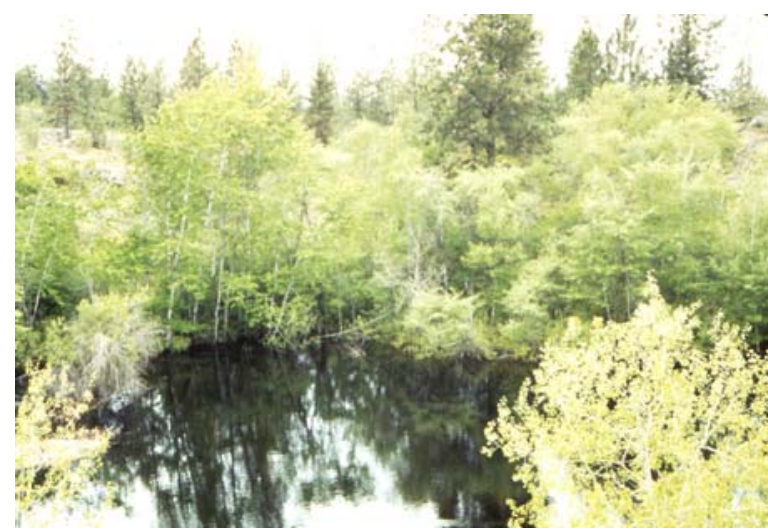

Figure 6. Spokane County, Washington water howellia pond

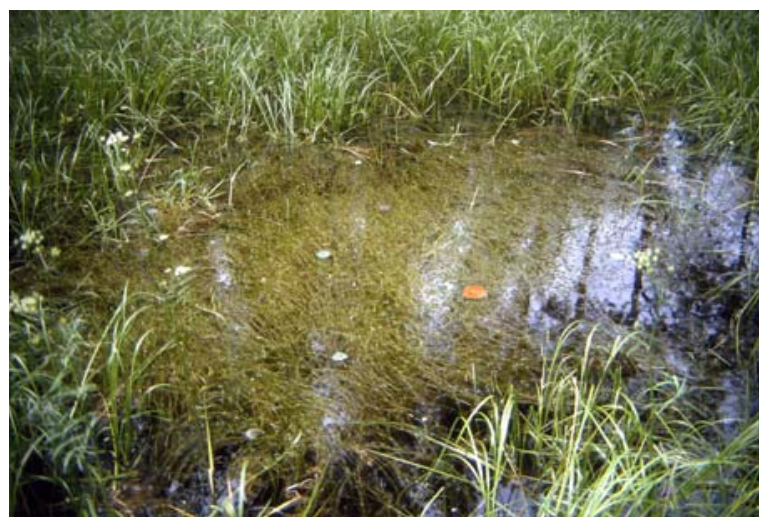

Figure 7. Lindbergh Lake, Montana water howellia pond (EO \#44)

Bottom surfaces of the ponds and wetlands usually consist of organic sediments underlain by consolidated clay (USFWS 1996). In Montana, soil units in the Swan Valley are comprised of Cryochepts, Eutroboralfs and Eutrochrepts from parent materials of clayey alluvium and clayey colluvium (Shelly and Moseley 1988). Soils on the 87,000 acre Fort Lewis Military Reservation are generally composed of nutrient poor, well-drained glacial till (Clegg and Lombardi 2000).

Analysis of water chemistry by Lesica (1992), Shapley (1998) and Reeves (2001) in the Swan Valley of Montana shows specific conductance readings from $<30 \mu \mathrm{S} / \mathrm{cm}$ to $400 \mu \mathrm{S} / \mathrm{cm}$ with most ponds below $150 \mu \mathrm{S} / \mathrm{cm}$. Measurements of $\mathrm{pH}$ ranged from 6.2 to 7.8 with most measurements between 6.5 and 7.5. The general conclusion drawn from these data is that water howellia prefers freshwater ponds close to neutral.

Prior to Shapley's analysis of the basin morphology of water howellia ponds in the Swan Valley, most ponds were considered to be closed under present climatic conditions (Shapley and Lesica 1997). However, 12 of 34 ponds studied were observed to have spill points occupied frequently enough to maintain some channel morphology and that interpond exchange of surface water during wet periods appeared to be more common than previously supposed. 
Table 2. Vascular plant species commonly associated with Howellia aquatilis sites by state. This is not meant to be an exhaustive list of all vascular species recorded at Howellia aquatilis sites. Data is derived from Heritage Program element occurrence records, Gilbert (2002), Gilbert and Lombardi (1999) and Shelly and Moseley (1988).

\begin{tabular}{|c|c|c|c|c|c|}
\hline Species & CA & ID & MT & OR & WA \\
\hline Abies grandis & & $\mathrm{X}$ & $\mathrm{X}$ & & \\
\hline Abies lasiocarpa & & & $\mathrm{X}$ & & \\
\hline Acer macrophyllum & & & & & $\mathrm{X}$ \\
\hline Acorus calamus & & $\mathrm{X}$ & & & \\
\hline Alisma plantago-aquatica & & $\mathrm{X}$ & $\mathrm{X}$ & & $\mathrm{X}$ \\
\hline Alnus incana & & $\mathrm{X}$ & $\mathrm{X}$ & & \\
\hline Alopecurus aequalis & & $\mathrm{X}$ & $\mathrm{X}$ & & $\mathrm{X}$ \\
\hline Amelanchier alnifolia & & $\mathrm{X}$ & & & \\
\hline Callitriche heterophylla & & $\mathrm{X}$ & $\mathrm{X}$ & & $\mathrm{X}$ \\
\hline Callitriche stagnalis & & & & & $\mathrm{X}$ \\
\hline Carex obnupta & & & & & $\mathrm{X}$ \\
\hline Carex serratodens & $\mathrm{X}$ & & & & \\
\hline Carex spp. & $\mathrm{X}$ & & & & \\
\hline Carex vesicaria & & $\mathrm{X}$ & $\mathrm{X}$ & & $\mathrm{X}$ \\
\hline Cicuta douglasii & & $\mathrm{X}$ & & & \\
\hline Cornus stolonifera & & $\mathrm{X}$ & $\mathrm{X}$ & & $\mathrm{X}$ \\
\hline Crataegus douglasii & & $\mathrm{X}$ & & & \\
\hline *Dactylis glomerata & & $\mathrm{X}$ & & & \\
\hline Eleocharis palustris & & $\mathrm{X}$ & $\mathrm{X}$ & $\mathrm{X}$ & $\mathrm{X}$ \\
\hline Epilobium oregonense & $\mathrm{X}$ & & & & \\
\hline Equisetum fluviatile & & & $\mathrm{X}$ & & $\mathrm{X}$ \\
\hline Fraxinus latifolia & & & & & $\mathrm{X}$ \\
\hline Glyceria borealis & $\mathrm{X}$ & & $\mathrm{X}$ & & \\
\hline Glyceria elata & $\mathrm{X}$ & $\mathrm{X}$ & & & \\
\hline Glyceria grandis & & $\mathrm{X}$ & & & \\
\hline Glyceria occidentalis & & $\mathrm{X}$ & & & $\mathrm{X}$ \\
\hline *Iris pseudacorus & & & & & $\mathrm{X}$ \\
\hline Juniperus communis & & & $\mathrm{X}$ & & \\
\hline Larix occidentalis & & & $\mathrm{X}$ & & \\
\hline Lemna minor & & $\mathrm{X}$ & & & $\mathrm{X}$ \\
\hline Lemna spp. & $\mathrm{X}$ & & & & \\
\hline Lonicera involucrata & & & & & $\mathrm{X}$ \\
\hline Ludwigia palustris & & & & $\mathrm{X}$ & $\mathrm{X}$ \\
\hline Mentha arvensis & & $\mathrm{X}$ & & & $\mathrm{X}$ \\
\hline Myosotis laxa & $\mathrm{X}$ & & & & $\mathrm{X}$ \\
\hline *Myosotis scorpioides & & $\mathrm{X}$ & & & $\mathrm{X}$ \\
\hline Nuphar polysepalum & & & & & $\mathrm{X}$ \\
\hline Oenanthe sarmentosa & & & & & $\mathrm{X}$ \\
\hline *Phalaris arundinacea & & $\mathrm{X}$ & $\mathrm{X}$ & & $\mathrm{X}$ \\
\hline Philadelphus lewisii & & & & & $\mathrm{X}$ \\
\hline Physocarpus capitatus & & $\mathrm{X}$ & & & \\
\hline Picea engelmannii & & $\mathrm{X}$ & $\mathrm{X}$ & & \\
\hline Pinus contorta & & $\mathrm{X}$ & $\mathrm{X}$ & & \\
\hline Pinus ponderosa & & $\mathrm{X}$ & $\mathrm{X}$ & & $\mathrm{X}$ \\
\hline
\end{tabular}




\begin{tabular}{|c|c|c|c|c|c|}
\hline Species & $\mathbf{C A}$ & ID & MT & OR & WA \\
\hline Polygonum coccinium & & & & & $\mathrm{X}$ \\
\hline Populus tremuloides & & & $\mathrm{X}$ & & $\mathrm{X}$ \\
\hline Populus trichocarpa & & & $\mathrm{X}$ & & $\mathrm{X}$ \\
\hline Potamogeton gramineus & & & $\mathrm{X}$ & & \\
\hline Potamogeton natans & & & & $\mathrm{X}$ & $\mathrm{X}$ \\
\hline Potamogeton nodosus & $\mathrm{X}$ & & & & \\
\hline Potamogeton pusillus & $\mathrm{X}$ & & & & \\
\hline *Prunus avium & & & & & $\mathrm{X}$ \\
\hline Pseudotsuga menziesii & & $\mathrm{X}$ & $\mathrm{X}$ & & \\
\hline Pyrus fusca & & & & & $\mathrm{X}$ \\
\hline Ranunculus aquatilis & $\mathrm{X}$ & & $\mathrm{X}$ & $\mathrm{X}$ & $X$ \\
\hline Ranunculus flabellaris & & $\mathrm{X}$ & & & $\mathrm{X}$ \\
\hline Ranunculus flammula & $\mathrm{X}$ & & & & $X$ \\
\hline Rhamnus alnifolia & & & $\mathrm{X}$ & & \\
\hline Salix bebbiana & & $\mathrm{X}$ & & & \\
\hline Salix drummondiana & & $\mathrm{X}$ & & & \\
\hline Salix lasiandra & & & & & $\mathrm{X}$ \\
\hline Salix spp. & & & $\mathrm{X}$ & & $\mathrm{X}$ \\
\hline Sium suave & & $\mathrm{X}$ & $\mathrm{X}$ & & $\mathrm{X}$ \\
\hline *Solanum dulcamara & & $\mathrm{X}$ & & & $\mathrm{X}$ \\
\hline Sparganium emersum & & $\mathrm{X}$ & & $\mathrm{X}$ & $\mathrm{X}$ \\
\hline Sparganium minimum & & & $\mathrm{X}$ & & \\
\hline Sparganium spp. & $\mathrm{X}$ & & & & \\
\hline Spiraea douglasii & & & & & $\mathrm{X}$ \\
\hline Symphoricarpos albus & & $\mathrm{X}$ & & & $\mathrm{X}$ \\
\hline Typha spp. & $\mathrm{X}$ & & & & \\
\hline Utricularia vulgaris & $\mathrm{X}$ & $\mathrm{X}$ & & & $\mathrm{X}$ \\
\hline Veronica anagallis-aquatica & & & & & $\mathrm{X}$ \\
\hline Veronica scutellata & & $\mathrm{X}$ & & & $\mathrm{X}$ \\
\hline
\end{tabular}

*non-native species

\section{G. Land Ownership}

The federal government manages lands that completely or partially encompass $82 \%$ of known Howellia aquatilis sites (see Table 1). One agency alone, the U.S. Forest Service (USFS), manages lands that encompass $57 \%$ or 124 of the total populations. In addition, the U.S. Fish and Wildlife Service (USFWS) manages lands where another 35 populations occur. All of the USFWS occurrences, except the Oregon population, occur in Washington. Also in Washington, 17 populations occupy lands owned by the U.S. Department of Defense (McChord Air Force Base and Fort Lewis). State agencies in Montana and Washington manage lands with another seven populations.
The remaining $15 \%$ of populations occur on a variety of privately owned lands. However, one population occurs on a Nature Conservancy Preserve in Montana, the Idaho population occurs on property willed to the Audubon Society (IDCDC database 2005) and 33 occurrences in Montana occur partially or entirely on Plum Creek Timber Company lands.

In Montana, 41 populations cross ownership boundaries with many of these occupying both Flathead National Forest lands, Plum Creek Timber Company lands or other privately owned lands. Land ownership in the Swan Valley, where all the Montana populations occur, is 
largely in a "checkerboard pattern" of National Forest, state lands, Plum Creek Timber Company and other private lands, resulting in part from the Railroad Land Grants in the late 1800 s.

\section{H. Potential Threats to Known Populations}

1. Human Land Use: A variety of land uses still pose potential threats to Howellia aquatilis across its range, including activities related to timber harvesting, land development, recreation, military activities, and grazing. A total of 67 occurrences in Montana and Washington occur partially or wholly on private lands that afford little or no protection from human impacts. Development of some of these private lands in the Swan Valley of Montana and Spokane County, Washington is still a possibility that could adversely affect not only populations on those lands but also populations on adjacent public lands.

On Fort Lewis Military Reservation, signs have been erected around all water howellia ponds noting the presence of a federally threatened wetland plant. Also, military operations do not generally occur in wetland habitats so direct impact to water howellia populations from military activities is not currently a problem. However, trampling of the drawdown zone, particularly in the Dailman wetland population, has been observed and is believed to be caused primarily by duck hunters (Gilbert and Lombardi 1999, Clegg and Lombardi 2000).

In the past, timber harvesting and related activities have been documented in and adjacent to water howellia ponds in the Swan Valley, including removal of overstory trees, road building and even deposition of logging slash in the water (Shelly 1988, Shelly and Moseley 1988, USFWS 1994). Timber harvesting impacts on Howellia aquatilis on USFS lands in the Swan Valley have been minimized with adoption of 300 foot protective buffers around occupied ponds as recommended in the Conservation Strategy (USDA Forest Service 1994, 1997). Measures to exclude cattle from ponds have also been implemented on the Flathead National Forest.

Plum Creek Timber Company has implemented a water howellia management plan on its lands that provides protection to this species. The plan calls for following all Montana Streamside Management Zone (SMZ) laws and Best Management Practices. For occurrences that aren't regulated under the SMZ law, Plum Creek calls for implementation of a no equipment zone or that activity should take place when the ground is frozen to minimize soil impacts and sedimentation. The plan also calls for protection of water howellia sites by incursion from cattle.

2. Natural Disturbances: Invasion of occupied water howellia sites by non-native species, particularly Phalaris arundinacea, has been a concern since the 1980's. Most of the $P$. arundinacea occurring in water howellia ponds is presumed to be of non-native origin. $P$. arundinacea occurs in many wetland and riparian sites in Idaho, Montana and Washington and has been documented in almost all Washington occurrences, the Idaho location and many Montana water howellia occurrences. In Montana, 20 of 68 ponds monitored by the Flathead National Forest are known to contain P. arundinacea (Davis 2004). Monitoring of water howellia ponds on the Flathead National Forest does show a slight increase in the frequency of $P$. arundinacea in the ponds from the initial monitoring year of 1998 but it has remained relatively stable the following five years (Davis 2004). Conversely, monitoring on the Swan River Oxbow Preserve in Montana by Lesica (1997) in the Phalaris-marsh ecotone shows an increase in $P$. arundinacea cover and a corresponding drop in $H$. aquatilis cover over a nine-year period. Though studies such as Lesica's do show that water howellia is negatively influenced in the immediate area of dense $P$. arundinacea stands, it is not known to what extent $P$. arundinacea will invade and form dense stands in water howellia ponds in Montana.

In Idaho, $P$. arundinacea has demonstrated the ability to completely invade and form dense stands in water howellia ponds. Clipping and 
excavating $P$. arundinacea in the Idaho ponds is on-going and water howellia was observed in 2004 in areas where $P$. arundinacea was removed. Additional species that are invading and competing with water howellia in Idaho include Solanum dulcamara and Acorus calamus (Gray 2005).

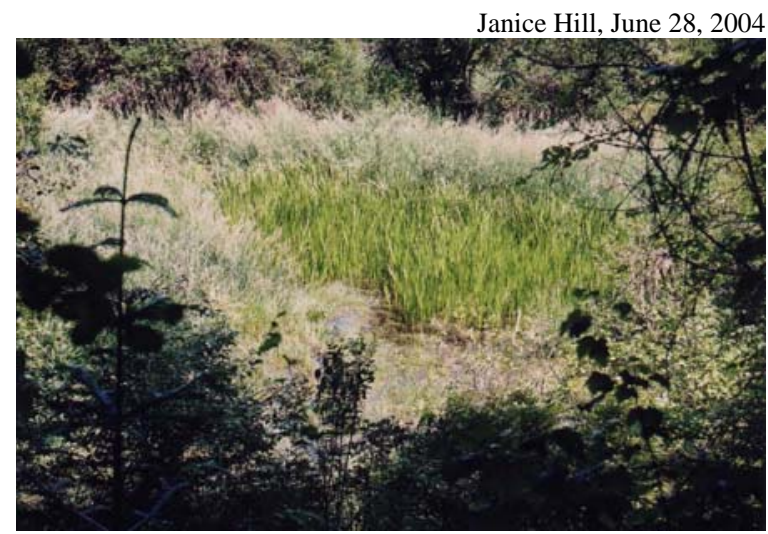

Figure 8. Idaho howellia pond dominated by Phalaris arundinacea (taller, lighter colored grass along outer edges) and Acorus calamus (darker, shorter species in middle of pond).

Iris pseudacorus (yellow flag iris), another nonnative species, has been invading water howellia wetlands on Fort Lewis and appears to be spreading rapidly in Shaver Kettle and the Chambers Lake complex. In 2003, an eradication program was initiated by hand pulling the species in the majority of the Chambers Lake complex. Results of this effort are not yet available (Gilbert 2001, Wolford 2003). The possible introduction of a Myriophyllum spp. (water milfoil) in the Dailman wetland has also been noted and is a cause for concern (Clegg and Lombardi 2000).

Lythrum salicaria (purple loosestrife) is another non-native wetland species that may yet pose problems in water howellia ponds. Quick response and eradication measures should be taken with these latter two species and any other new invasives at all water howellia sites.

Long-term weather patterns also have a direct and potentially negative impact on water howellia. Consecutive years of drought or exceedingly wet years pose problems for water howellia as previously mentioned. Monitoring data have shown that seeds apparently remain viable for up to three years, though viability is probably substantially reduced (Lesica 1992). The potential for a severe reduction or eradication of the species in a geographic area does exist during several years of consecutive drought. On Fort Lewis, unsuitable water levels are identified as one of two primary threats to water howellia populations, the other being wetland plant succession (Wolford 2003).

\section{Assessment and Recommendations}

\section{A. General Assessment of Trends and Status}

Total population numbers for Howellia aquatilis, as with any annual species, are difficult to estimate without quantitative survey data over many years. There is a general lack of quantitative survey data for the majority of water howellia occurrences. Approximately $1 / 4$ of the known populations have only been visited once and even if the population size was estimated during that site visit, abundance varies dramatically from year to year depending on climate and other factors. Accurate and precise measures or estimates of abundance are difficult to collect due to the aquatic nature of the plant. This annual variation and difficulty in collecting accurate survey data means that it takes many years of data across the range of the species to adequately estimate population size. If the sum of the minimum and maximum number of plants estimated at each occurrence are used as a basis for the species total population, a range of $18,000-138,000$ plants is derived. A sum of the median population size for each occurrence results in a figure of approximately 51,000 plants. Range-wide population estimates derived from quantitative sampling data are available by year in Figure 8.

Since abundance varies widely year to year, a single estimate does not provide very meaningful data about a particular population. In fact, over 50 occurrences have only been surveyed once and another 45 locations have 
only been surveyed twice (Figure 9). One or two visits to an individual population do not provide enough sample points to make an assessment of that population's general size and importance to the overall viability of the species.

Another important aspect to consider is the number of individual occurrences. The number of known populations or occurrences, though not necessarily a good predictor of a species' viability or trend, at least provides documentation about the species over time. Over the past two decades, the number of documented occurrences has more than doubled from 72 in 1988 to 214 in 2004 (Table 3). In the past four years alone, approximately two-dozen new occurrences have been documented. It is not unrealistic to expect that just as many new occurrences may be documented in the next four to five years if intensive surveys are conducted and weather conditions are favorable to the species' biology.

Table 3. Number of known Howellia aquatilis occurrences by year.

\begin{tabular}{|c|c|c|}
\hline Year & $\begin{array}{c}\text { \# of } \\
\text { Occurrences }\end{array}$ & Source \\
\hline 1988 & 72 & Shelly and Moseley 1988 \\
\hline 1990 & 76 & Schassberger and Shelly 1990 \\
\hline 1992 & 76 & Roe and Shelly 1992 \\
\hline 1993 & $79^{*}$ & USFWS 1993 \\
\hline 1994 & $107^{* *}$ & USFWS 1994 \\
\hline 1996 & 160 & USFWS 1996 \\
\hline 1997 & 170 & USFS 1997 \\
\hline 1998 & 180 & $\begin{array}{c}\text { Forum on research and } \\
\text { management of Howellia } \\
\text { aquatilis 1998 }\end{array}$ \\
\hline 2000 & 199 & Natural Heritage Program data \\
\hline 2004 & 214 & Natural Heritage Program data \\
\hline
\end{tabular}

* Number of known occurrences at time of proposed federal listing under the Endangered Species Act.

** Number of known occurrences at time of federal listing under the Endangered Species Act.

Figure 9 provides data on the number of occurrences sampled each year and the associated estimate of population size for that year. Additionally, the number of new occurrences “discovered” each year is provided. Wide fluctuations in population estimates among years are directly tied to the number of populations sampled, suitable growing conditions that year and suitable germination conditions the previous year. Also directly influencing estimates of population size for any given year is whether or not a sampled population was given a quantitative measure of abundance or just the presence (or a qualitative abundance) of water howellia was noted.

The occupied habitat of water howellia was estimated at less than 200 acres at the time of listing (USFWS 1994). A current analysis of the area mapped using Natural Heritage Program data estimates a total occupied area of 285 acres. This estimate is derived by using the actual area mapped for all Montana occurrences plus figures provided by the four other states in which the species occurs. Occurrences that do not have an estimated or mapped area were given a figure of 0.1 acre. The majority of occupied habitat occurs in two metapopulations: 119 acres in the Swan Valley of Montana and 129 acres on Fort Lewis in Pierce County, Washington. The actual occupied habitat might be higher if more accurate data were available for California and numerous Washington populations. However, the area occupied by the species in any given year is probably far less than the 285 acres estimated as occupied habitat.

It is unknown how widespread the species was before European settlement and modern development in the Pacific Northwest. Including historical collections of the species does not significantly increase the range of the species. Though previous reports have presented the idea that the species was more widespread across the region, there are no "concrete" data to support this claim and the area occupied by the species was probably small even before European settlement of the Pacific Northwest due to the narrow habitat requirements of the species. Since it was proposed for listing under the ESA in 1993, rediscoveries of the species in California, Oregon and Pierce County, Washington have extended the currently known range to generally cover known historical collection locations (USFWS 1993). 
Transplant studies of water howellia into unoccupied though apparently suitable habitat occurred in the Swan Valley, Montana in 1989. Fifteen soil plugs taken from a dense water howellia population were deposited into four unoccupied ponds. Two of these ponds contained water at the time of the transplant and it is presumed never dried out. Subsequent monitoring of these ponds the following two years did not detect any water howellia. The other two ponds did support small populations in 1990 and 1991 (Schassberger and Shelly 1991, Roe and Shelly 1992). Pond A (MT EO\# 130) was also observed to have two plants in 1992 and monitoring in 2001 documented four plants. 


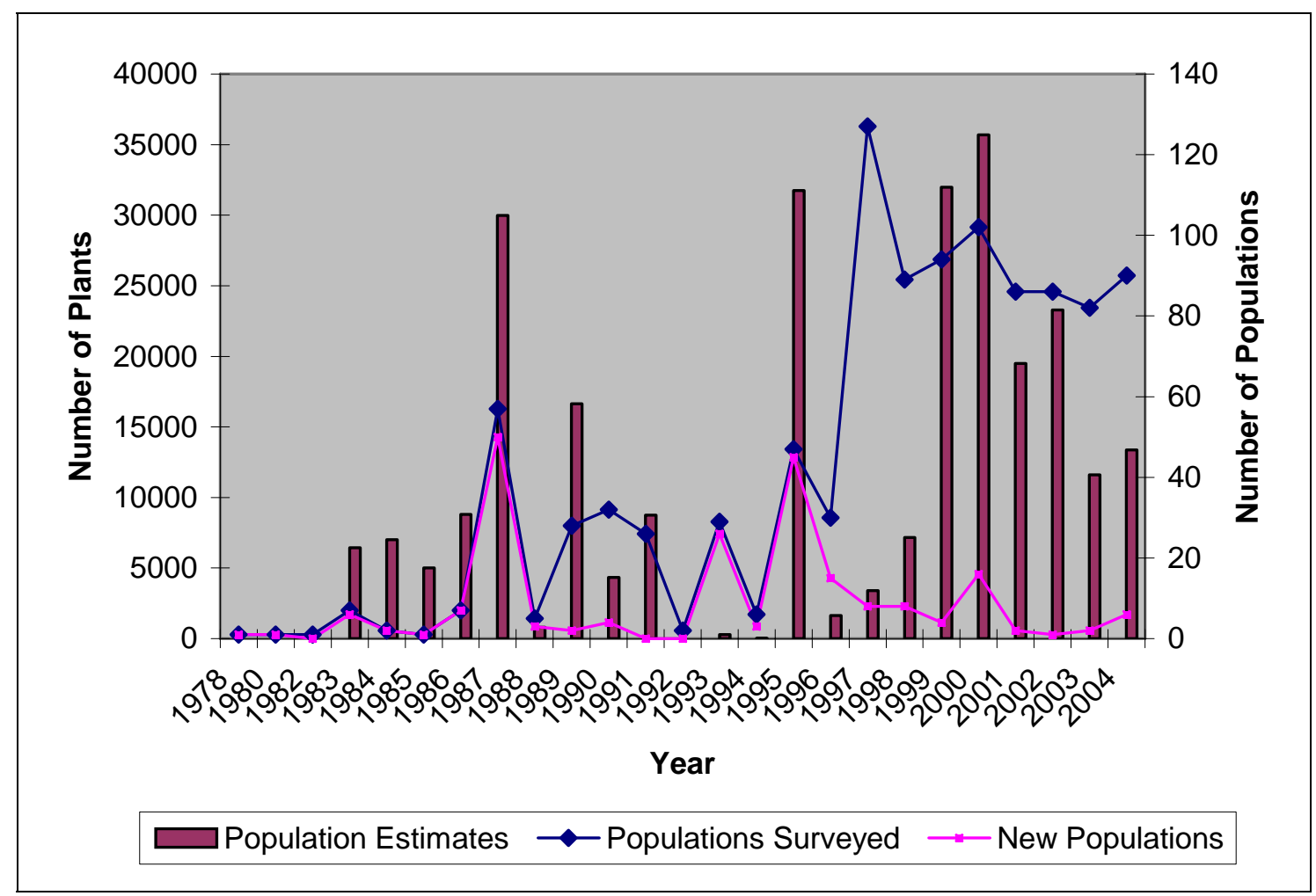

Figure 9. Relationship between number of $H$. aquatilis populations observed (sampled) and number of plants estimated each sample year. Not all populations are revisited each year and many sampled populations do not have an associated quantitative measure of abundance. Also included is the number of new populations found in that given year.

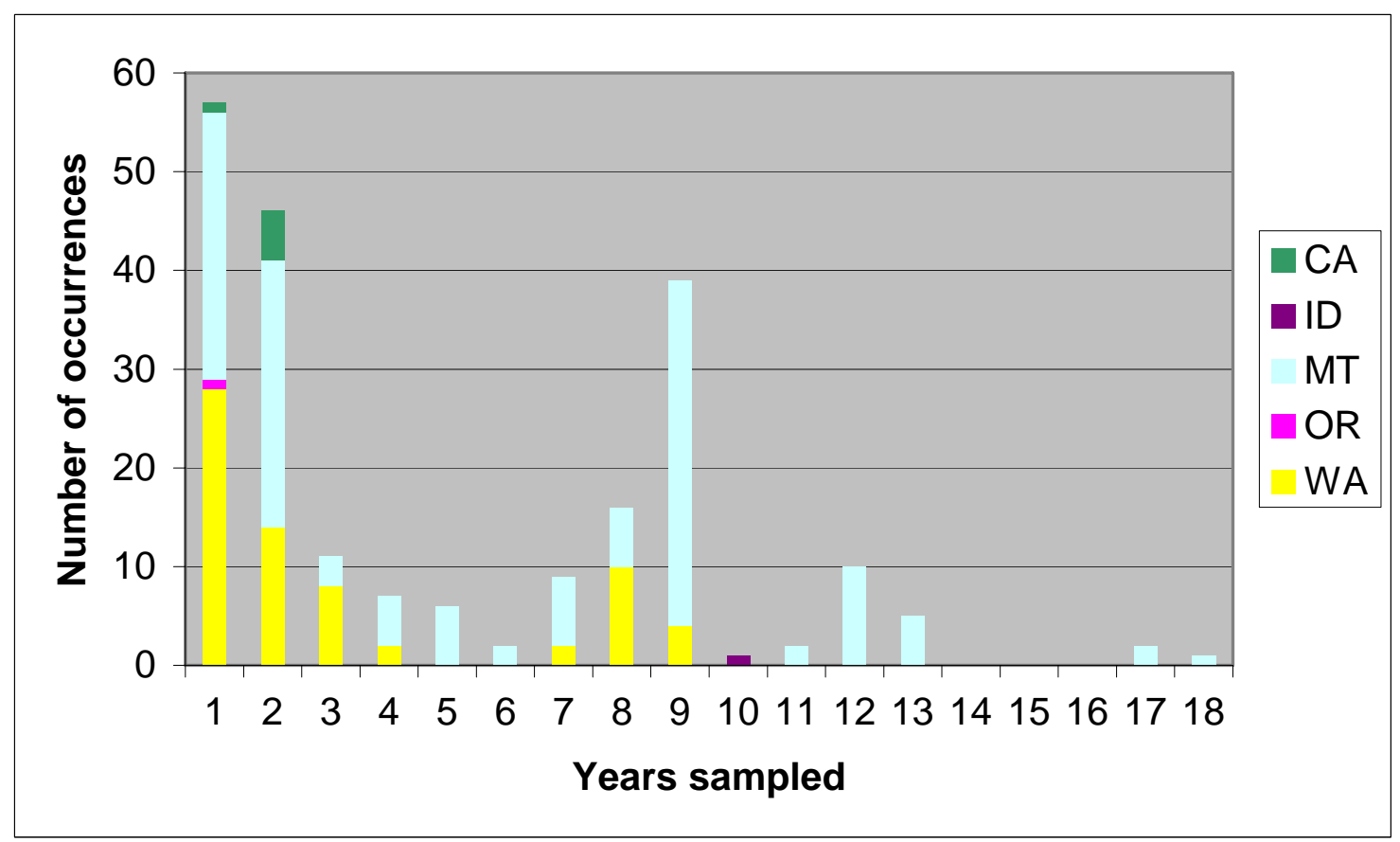

Figure 10. Sampling intensity of individual $H$. aquatilis occurrences stratified by state and number of years sampled. 
A semi-quantitative assessment was conducted using the approaches outlined by Regan, Master and Hammerson (2004) and adapted by the Montana Natural Heritage Program for use in ranking animal species of concern (MTNHP 2004). Both of these similar assessment methods assign points to factors such as number of occurrences, population size, area or range extent, trends and threats. Some factors may not be used if data are missing or an estimate of the parameter is too uncertain. The points from the most pertinent criteria are added together to form a final score for the species. Lastly, a Heritage rank of 1 to 5 at a Global and/or State level is assigned based on the final score. The ranking criteria and scores assigned for the $H$. aquatilis Global assessment are found in Table 4 using the two slightly different scoring methods.

Table 4. Ranking factors and assigned scores for the $H$. aquatilis global status assessment. The first point allocation numbers are those used in the scoring method of Regan, Master and Hammerson (2004) and the second point scores are those used in the method outlined by the MTNHP State rank criteria for animal species of concern. See Regan, Master and Hammerson (2004) and MTNHP (2004) for a complete discussion of the methodologies.

\begin{tabular}{|c|c|c|c|}
\hline Factor & Parameter Estimate & Category & Point Allocation \\
\hline \# of Occurrences & $81-300$ & D & 4/Not used \\
\hline $\begin{array}{l}\text { Condition of } \\
\text { Occurrences }\end{array}$ & $\begin{array}{l}\text { Many (41-125) with good or } \\
\text { excellent viability }\end{array}$ & $\mathrm{E}$ & 0/Not used \\
\hline Population Size & 10,000-100,000 plants & $\mathrm{F}$ & $0 / 0$ \\
\hline $\begin{array}{c}\text { Area of } \\
\text { Occupancy }\end{array}$ & $0.4-4$ km2 (100-1,000 acres) & B & Not used/Not Used \\
\hline $\begin{array}{l}\text { Geographic } \\
\text { Range }\end{array}$ & $\begin{array}{l}\text { 1,000-5,000 km2? (400- } \\
\text { 2,000 sq. miles) }\end{array}$ & $\mathrm{D}$ & Not used/-0.25 \\
\hline Long-term Trend & $\begin{array}{c}\text { Relatively stable (+- 25\% } \\
\text { change) }\end{array}$ & $\mathrm{E}$ & 0 \\
\hline Short-term Trend & Stable & $\mathrm{E}$ & 0 \\
\hline Threats-Severity & Moderate & \multirow{3}{*}{ B } & \multirow{3}{*}{$-0.75 /-0.75$} \\
\hline Threats-Scope & Moderate to high & & \\
\hline $\begin{array}{c}\text { Threats- } \\
\text { Immediacy }\end{array}$ & Moderate to high & & \\
\hline $\begin{array}{c}\text { Intrinsic } \\
\text { Vulnerability } \\
\end{array}$ & Highly vulnerable & A & Not used/Not used \\
\hline \multirow[t]{4}{*}{$\begin{array}{c}\text { Environmental } \\
\text { Specificity }\end{array}$} & \multirow[t]{4}{*}{$\begin{array}{l}\text { Very narrow with key } \\
\text { requirements scarce }\end{array}$} & A & Not used/Not used \\
\hline & & Initial Point Allocation & $0 / 3.5$ \\
\hline & & Score & $3.25 / 2.5$ \\
\hline & & Rank & G3/G2 \\
\hline
\end{tabular}

The assignment of the threat attributes of severity, scope and immediacy is still a mostly subjective process and as such is open to interpretation and discussion. The most apparent threats to the viability of the species appear to be from the high degree of environmental specificity, competition, loss of habitat due to weed invasion and from the species' own biology and large yearly fluctuations in population size due to dependence on favorable environmental conditions in the current and previous years. 


\section{B. Status Recommendations}

1. NatureServe: The NatureServe Global Rank for water howellia was changed from a "G2" to a "G3" in February 2004 (NatureServe 2005). Results of this range-wide status assessment generally support the "G3" rank, though the species is still close to a "G2" rank due to the small amount of occupied habitat, the clustering of most populations in three main population centers and the threat posed by invasive species.

2. Federal Status: The Draft Recovery Plan for Howellia aquatilis (USFWS 1996) listed three primary criteria that must be met for delisting to occur.

It states that, "Delisting will be considered when all the following conditions have been met:

1. Management practices, in accordance with habitat management plans, have reduced and/or controlled anthropogenic threats, thereby maintaining the species and its habitat integrity throughout the currently known range on public lands in five geographic areas for ten years after the effective date of the recovery plan. Monitoring will demonstrate effectiveness of management plans. Management plans will be in place for, at minimum, the following occurrences:

a. 67 occurrences in the Montana geographic area.

b. 33 occurrences in the Spokane County, WA geographic area.

c. 5 occurrences in the Pierce County, WA, geographic area.

d. 4 occurrences in the Clark County, WA, geographic area.

e. 5 occurrences in the Mendocino County, CA, geographic area.

2. Conservation of occurrences on lands not addressed in agency management plans, including those that are within metapopulations as well as outlying geographic extensions, is fostered. Confirm the long-term conservation measures are in place for the occurrence in Latah County, Idaho.

3. A post-listing strategy for monitoring the species population dynamics is in place.”

Established monitoring programs on the Flathead National Forest, Montana and on Fort Lewis/McChord Air Force Base in Pierce County, Washington have made great progress in meeting the objectives listed in 1a and 1c. Seven years of monitoring data are now available for 68 ponds from the Flathead National Forest's current monitoring strategy and on Fort Lewis, Washington for 15 ponds from monitoring conducted by the Land Condition Trend Analysis Program. In addition, annual monitoring of the Idaho population has been in place since 1999. Monitoring programs are not known to have been implemented in other areas of the species' range.

Two populations are afforded protection by conservation organizations. The Swan River Oxbow population as part of a Nature Conservancy Preserve and the Idaho population is included in land willed to the Audubon Society. Other significant populations on private lands should be protected as part of the long-term conservation of the species.

Updating and finalizing a recovering strategy should be a primary step in the move towards potential delisting. Establishing criteria or conditions for delisting is not the primary purpose of this assessment. However, several recommended conditions for potential delisting are provided below:

1. Continuation of monitoring programs on the Flathead National Forest, Montana, Fort Lewis/McChord Air Force Base in Pierce County, Washington and in Latah County, Idaho so that a minimum of ten years worth of data are available for those areas.

2. Annual monitoring of populations in Mendocino County, California, the Latah County, Idaho and Benton County, Oregon occurrences, the occurrence on the Swan River Oxbow Preserve in Montana, and all 
occurrences on public lands in Washington so that a minimum of 5 years of recent data are available for those populations. Additionally, occurrences on private lands in Spokane County, Washington and the Swan Valley, Montana should be monitored to the extent feasible.

Similar monitoring methods to those employed by the Flathead National Forest, Montana and the Land Condition Trend Analysis Program on Fort Lewis, Washington appear to provide a sound methodology for collecting quantitative survey data in a challenging setting with the requirement of limiting damage to the species. These programs divide the sample ponds in thirds and quarters respectively and estimate the number of plants using one of four abundance classes in each section. A measure of the abundance of Phalaris arundinacea and other weedy species should also be incorporated into all monitoring programs.

3. Management plans in place for all occurrences on federal lands across the range of the species, including control strategies for $P$. arundinacea and other invasive weeds, if needed. Control programs for $P$. arundinacea and Iris pseudacorus implemented on Fort Lewis, Washington and in Idaho consist primarily of hand pulling and/or clipping these and other invasive species. Similar control measures should be taken across the range of water howellia where invasive species are encroaching into known water howellia habitat.

4. Implementation of conditions 2 and 3 as outlined in the draft recovery plan and listed above.

If monitoring of populations as described in recommendations 1 and 2 above finds that populations are stable though with large yearly fluctuations and management plans and conservation strategies are in place as recommended above, then delisting may be warranted.

The annual nature of the species in conjunction with its narrow ecological niche makes it vulnerable to long-term unfavorable weather patterns and climate change. In addition, the clustering of populations in just a few geographic areas also makes it more susceptible to regional and local influences. Invasion of the species' habitat by non-native species is also a problem that most likely will continually need to be addressed. However, the majority of known populations occur on public lands providing the opportunity for the implementation of conservation measures and strategies beneficial to the long-term survival of the species. Many additional populations occur on Plum Creek Timber Company lands in the Swan Valley of Montana, which may provide additional opportunities for conservation. With implementation of management plans, continued monitoring and conservation protection of additional populations, delisting should be an achievable goal. 


\section{LITERATURE CiTED}

Brunsfeld, S.J. and C.T. Baldwin. 1998.

Howellia aquatilis genetics: not so boring after all. In: Forum on Research and Management of Howellia aquatilis. Turnbull National Wildlife Refuge, Cheney, WA. March 24-25.

California Natural Diversity Database. 2005. Natural Diversity Database - February 6, 2005. Sacramento, CA.

Clegg, M. and A. Lombardi. 2000. Status report for water howellia (Howellia aquatilis) on Fort Lewis, WA. Report to the Land Condition Trend Analysis Program, Fort Lewis, WA. Environment and Engineering Inc., Norfolk, VA. 19 pp.

Davis, L. 2004. Flathead National Forest, FY05 - year report of annual monitoring requirements - annual monitoring of water howellia occurrences. Unpublished report. Flathead National Forest, MT.

Gilbert, R. 2002. Field report for water howellia surveys on Fort Lewis, WA. Report to the Land Condition Trend Analysis Program, Fort Lewis, WA. Environment and Engineering Inc., Norfolk, VA. 17 pp.

Gilbert, R. 2001. Status report for water howellia (Howellia aquatilis) on Fort Lewis, WA. Report to the Land Condition Trend Analysis Program, Fort Lewis, WA.

Environment and Engineering Inc., Norfolk, VA. 9 pp.

Gilbert, R. and A. Lombardi. 1999. Status report for water howellia (Howellia aquatilis) on Fort Lewis, WA. Report to the Land Condition Trend Analysis Program, Fort Lewis, WA. Environment and Engineering Inc., Norfolk, VA. 25 pp.

Gray, K. 2005. Personal Communication.

Holmgren P.K. and N.H. Holmgren. 1990. Index Herbariorum, Edition 8: Part I. The Herbaria of the World. New York Botanical
Garden Press. 704 pp. on-line

(http://207.156.243.8/emu/ih/index.php).

Idaho Conservation Data Center. 2005. ID

CDC Database - February 25, 2005. ID

Department of Fish and Game, Boise, ID.

Isle, D.W. 1997. Rediscovery of water howellia for California. Fremontia 25(3): 29-32.

Lesica, P. 1997. Spread of Phalaris arundinacea adversely impacts the endangered plant Howellia aquatilis. Great Basin Naturalist 57(4): 366-368.

Lesica, P. 1992. Autecology of the endangered plant Howellia aquatilis; implications for management and reserve design. Ecological Applications 2(4): 411-421.

Lesica, 1990. Habitat requirements, germination behavior and seed bank dynamics of Howellia aquatilis in the Swan Valley, MT. Unpublished report to the USDA Forest Service, Flathead National Forest, MT. Conservation Biology Research, Missoula, MT. 44 pp. + appendices.

Lesica, P., R.F. Leary, F.W. Allendorf and D.E. Bilderback. 1988. Lack of genetic diversity within and among populations of an endangered plant, Howellia aquatilis. Conservation Biology 2(3): 275-282.

McCune, B. 1982. Noteworthy collections, Montana: Howellia aquatilis. Madrono 29:123124.

Montana Natural Heritage Program. 2005. Biotics Database - June 24, 2005. Helena, MT.

Montana Natural Heritage Program. 2004 State rank criteria for animal species of concern. online

(http://nhp.nris.state.mt.us/animal/index.html).

NatureServe. 2005. NatureServe Explorer: An online encyclopedia of life [web application]. Version 4.4. NatureServe, Arlington, Virginia. Available http://www.natureserve.org/explorer. 
Oregon Natural Heritage Program. 2005. OR NHP Database - February 28, 2005. Portland, OR.

Reeves, D.M. 2001. Hydrologic controls on the survival of water howellia (Howellia aquatilis) and implications of land management, Swan Valley, MT. M.S. Thesis, The University of Montana, Missoula. 71 pp. + appendices.

Regan, T.J., L.L. Master and G.A. Hammerson. 2004. Capturing expert knowledge for threatened species assessments: a case study using NatureServe conservation status ranks. Acta Oecologica 26:95-107.

Roe, L.S. and J.S. Shelly. 1992. Update to the status review of Howellia aquatilis: field surveys, monitoring studies and transplant experiments. Report to the USDA Forest Service, Flathead National Forest. Montana Natural Heritage Program, Helena, MT. 51 pp.

Schassberger, L.A. and J.S. Shelly. 1991. Update to the status review of Howellia aquatilis: field surveys, monitoring studies and transplant experiments. Report to the USDA Forest Service, Flathead National Forest. Montana Natural Heritage Program, Helena, MT. 57 pp.

Shapley, M. 1998. Preliminary evaluation of basin morphometry and field chemistry of Montana's Howellia aquatilis ponds.

Unpublished report to the Flathead National Forest, Kalispell, MT and U.S. Fish and Wildlife Service, Denver, CO. Montana Natural Heritage Program, Helena, MT. 7 pp. + figures and tables.

Shapley, M.D. and P. Lesica. 1997. Howellia aquatilis (water howellia) ponds of the Swan Valley: Conceptual hydrologic models and ecological implications. Report to the U.S. Fish and Wildlife Service, Denver, CO. Montana Natural Heritage Program, Helena, MT and Conservation Biology Research, Missoula, MT. $44 \mathrm{pp}$.

Shelly, J.S. 1989. Addendum to the status review of Howellia aquatilis, U.S. Forest
Service, Region 1, Flathead National Forest. Montana Natural Heritage program, Helena, MT. 17 pp.

Shelly, J.S. 1988. Status review of Howellia aquatilis, U.S. Forest Service, Region 1, Flathead National Forest. Montana Natural Heritage Program, Helena, MT. 120 pp.

Shelly, J.S. and R. Moseley. 1988. Report on the conservation status of Howellia aquatilis, a candidate threatened species. Montana Natural Heritage Program, Helena, MT. 74 pp. + appendices.

USDA Forest Service. 1997. Conservation strategy for Howellia aquatilis A. Gray (second edition). USDA Forest Service, Flathead National Forest. 24 pp.

USDA Forest Service. 1994. Conservation strategy for Howellia aquatilis A. Gray. USDA Forest Service, Flathead National Forest. 26 pp.

U.S. Fish and Wildlife Service. 1996. Water howellia (Howellia aquatilis) recovery plan, public and agency review draft. Report to the U.S. Fish and Wildlife Service. 52 pp.

U.S. Fish and Wildlife Service. 1994.

Endangered and threatened wildlife and plants; the plant water howellia (Howellia aquatilis), determined to be a threatened species. Federal Register 59(134): 35860-35864.

U.S. Fish and Wildlife Service. 1993.

Endangered and threatened wildlife and plants; Proposed listing of water howellia (Howellia aquatilis) as threatened. Federal Register 58(72): 19795-19800.

Washington Natural Heritage Program. 2005. WA Natural Heritage Information System March 2, 2005. Olympia, WA.

Wolfold, L. 2004. Water howellia (Howellia aquatilis) monitoring on Fort Lewis Military Reservation field report, 2004. Report to the Land Condition Trend Analysis Program, Fort Lewis, WA. Environment and Engineering Inc., Norfolk, VA. 22 pp. 
Wolfold, L. 2003. Water howellia monitoring on Fort Lewis, 2003. Report to the Land Condition Trend Analysis Program, Fort Lewis, WA. Environment and Engineering Inc., Norfolk, VA. 17 pp. 


\section{APPENDiX A. HoWellia AQUATILIS OCCURRENCE DATA BY STATE AND ELEMENT OCCURRENCE NUMBER}


Appendix A. Howellia aquatilis occurrence data by state and Element Occurrence number. Size in acres is generally the area mapped and not the necessarily the area occupied by the species, which is generally smaller in any given year. Summary statistics of Minimum, Maximun, Mean and

Median population estimates are provided for each occurrence. These figures are derived from the yearly quantitative data available for each occurrence, which may be less than the total number of years visited. Rank follows the NatureServe Element Occurrence rank definitions (Appendix E) and was derived primary from recent estimates of population size.

\begin{tabular}{|c|c|c|c|c|c|c|c|c|c|c|c|c|}
\hline State & EO\# & Name & Ownership & County & Elevation (ft) & Size (ac) & Years visited & Min & $\operatorname{Max}$ & Mean & Median & Rank \\
\hline $\mathrm{CA}$ & 1 & -- & Mendocino National Forest & Mendocino & 3520 & -- & 2 & 75 & 200 & 138 & 137.5 & $A C$ \\
\hline $\mathrm{CA}$ & 2 & -- & Mendocino National Forest & Mendocino & 4500 & -- & 1 & 25 & 25 & 25 & 25 & C? \\
\hline $\mathrm{CA}$ & 3 & -- & Mendocino National Forest & Mendocino & 3710 & 2.1 & 2 & 25 & 30 & 28 & 27.5 & C? \\
\hline CA & 4 & -- & Mendocino National Forest & Mendocino & 4000 & -- & 2 & 200 & 2000 & 1100 & 1100 & A? \\
\hline $\mathrm{CA}$ & 5 & -- & Mendocino National Forest & Mendocino & 4240 & -- & 2 & 10 & 10 & 10 & 10 & $\mathrm{D}$ ? \\
\hline CA & 6 & -- & Mendocino National Forest & Mendocino & 3760 & -- & 2 & -- & -- & -- & -- & $U$ \\
\hline ID & 1 & Harvard-Palouse River & Private (willed to Audubon Soc.) & Latah & 2560 & 0.3 & 10 & 30 & 3000 & 696 & 100 & A \\
\hline MT & 1 & Lindbergh Lake & Flathead National Forest & Missoula & 4230 & 0.5 & 13 & 0 & 500 & 134 & 75 & $B$ \\
\hline MT & 2 & Lindbergh Lake & Flathead NF/Plum Creek Timber Co & Missoula & 4175 & 1.7 & 3 & 2500 & 6500 & 4500 & 4500 & A? \\
\hline MT & 3 & Lindbergh Lake & Flathead NF/Private & Missoula & 4150 & 0.4 & 2 & 10 & 5000 & 2505 & 2505 & A? \\
\hline MT & 4 & Lindbergh Lake & Flathead NF/Private & Missoula & 4070 & 0.9 & 4 & 0 & 30 & 15 & 15 & $\mathrm{D} ?$ \\
\hline MT & 5 & Swan River Oxbow & The Nature Conservancy & Lake & 3100 & 17.9 & 11 & 0 & 5000 & 3333 & 5000 & A \\
\hline MT & 6 & Condon Creek & Flathead National Forest & Missoula & 3740 & 0.6 & 12 & 25 & 2000 & 791 & 450 & A \\
\hline MT & 7 & Swan River West & Flathead National Forest & Lake & 3190 & 0.6 & 12 & 50 & 3500 & 725 & 300 & A \\
\hline MT & 8 & Lost Creek Bench & Flathead National Forest & Lake & 3190 & 0.5 & 17 & 0 & 2500 & 526 & 175 & A \\
\hline MT & 9 & Lost Creek-Cilly Creek Ponds & Flathead National Forest & Lake & 3250 & 1.3 & 13 & 0 & 750 & 205 & 150 & A \\
\hline MT & 10 & Lost Creek-Cilly Creek Ponds & Flathead National Forest & Lake & 3230 & 0.3 & 9 & 0 & 250 & 69 & 37.5 & C \\
\hline MT & 11 & Lost Creek-Cilly Creek Ponds & Flathead National Forest & Lake & 3290 & 3.4 & 2 & 150 & 150 & 150 & 150 & $\mathrm{~B}$ ? \\
\hline MT & 12 & Lost Creek-Cilly Creek Ponds & Flathead National Forest & Lake & 3235 & 0.5 & 11 & 0 & 450 & 114 & 42.5 & $\mathrm{~B}$ \\
\hline MT & 13 & Lost Creek-Cilly Creek Ponds & Flathead National Forest & Lake & 3240 & 0.6 & 13 & 0 & 1200 & 302 & 225 & A \\
\hline MT & 14 & Lost Creek-Cilly Creek Ponds & Flathead National Forest & Lake & 3245 & 0.3 & 12 & 0 & 500 & 163 & 150 & A \\
\hline MT & 15 & Lost Creek-Cilly Creek Ponds & Flathead National Forest & Lake & 3245 & 0.2 & 9 & 0 & 300 & 122 & 150 & A \\
\hline MT & 16 & Lost Creek-Cilly Creek Ponds & Flathead National Forest & Lake & 3235 & 0.4 & 12 & 0 & 1200 & 310 & 300 & A \\
\hline MT & 17 & Lost Creek-Cilly Creek Ponds & Flathead National Forest & Lake & 3245 & 1.1 & 5 & 0 & 15 & 5 & 0 & $\mathrm{D}$ \\
\hline MT & 18 & Dog Creek & Flathead National Forest & Lake & 3660 & 0.8 & 9 & 0 & 450 & 241 & 262.5 & A \\
\hline MT & 19 & Dog Creek & Flathead National Forest & Lake & 3580 & 1.5 & 9 & 0 & 900 & 411 & 325 & $A$ \\
\hline MT & 20 & Condon Creek & Flathead National Forest & Missoula & 3740 & 0.4 & 18 & 0 & 5000 & 677 & 210 & $A$ \\
\hline MT & 21 & Condon Creek & Flathead National Forest & Missoula & 3740 & 1.7 & 3 & 0 & 50 & 25 & 25 & $C ?$ \\
\hline MT & 22 & Condon Creek & Flathead National Forest & Missoula & 3750 & 0.1 & 12 & 0 & 750 & 161 & 150 & A \\
\hline
\end{tabular}

Appendix A - 1 


\begin{tabular}{|c|c|c|c|c|c|c|c|c|c|c|c|c|}
\hline State & EO\# & Name & Ownership & County & Elevation (ft) & Size (ac) & Years visited & Min & $\operatorname{Max}$ & Mean & Median & Rank \\
\hline MT & 23 & Condon Creek & Flathead National Forest & Missoula & 3740 & 0.4 & 13 & 0 & 450 & 138 & 150 & A \\
\hline MT & 24 & Condon Creek & Flathead National Forest & Missoula & 3740 & 0.3 & 9 & 0 & 150 & 42 & 25 & $\mathrm{~B}$ \\
\hline MT & 25 & Condon Creek & Flathead National Forest & Missoula & 3750 & 0.7 & 12 & 0 & 325 & 104 & 25 & B \\
\hline MT & 26 & Condon Creek & Flathead National Forest & Missoula & 3710 & 0.4 & 12 & 25 & 1500 & 445 & 250 & $A$ \\
\hline MT & 27 & Condon Creek & Flathead National Forest & Missoula & 3690 & 0.7 & 17 & 0 & 450 & 225 & 262.5 & A \\
\hline MT & 28 & Condon Creek & Plum Creek Timber Company & Missoula & 3685 & 0.3 & 4 & 0 & 225 & 56 & 0 & $\mathrm{~B} ?$ \\
\hline MT & 29 & Condon Creek & Plum Creek Timber Company & Missoula & 3690 & 0.4 & 7 & 0 & 650 & 203 & 157.5 & $A C$ \\
\hline MT & 30 & Condon Creek & Plum Creek Timber Company & Missoula & 3740 & 0.3 & 5 & 0 & 1000 & 504 & 507.5 & $\mathrm{AC}$ \\
\hline MT & 31 & Condon Creek & Plum Creek Timber Company & Missoula & 3620 & 0.7 & 4 & 0 & 160 & 40 & 0 & $\mathrm{CD}$ \\
\hline MT & 32 & Lindbergh Lake & Flathead NF/Private & Missoula & 4165 & 0.3 & 5 & 5 & 900 & 352 & 30 & B \\
\hline MT & 33 & Lindbergh Lake & Flathead NF/Private & Missoula & 4130 & 2.4 & 2 & 50 & 50 & 50 & 50 & $\mathrm{C} ?$ \\
\hline MT & 34 & Lindbergh Lake & Flathead NF/Private & Missoula & 4145 & 0.3 & 2 & 60 & 60 & 60 & 60 & C? \\
\hline MT & 35 & Lindbergh Lake & Flathead NF/Private & Missoula & 4150 & 0.2 & 5 & 0 & 600 & 233 & 50 & $\mathrm{~B}$ \\
\hline MT & 36 & Lindbergh Lake & Flathead NF/Private & Missoula & 4190 & 0.5 & 2 & 20 & 120 & 70 & 70 & $\mathrm{BC}$ \\
\hline MT & 38 & Lindbergh Lake & Flathead NF/Plum Creek Timber Co & Missoula & 4130 & 1.1 & 2 & 2 & 1100 & 551 & 551 & $A ?$ \\
\hline MT & 39 & Lindbergh Lake & Flathead NF/Plum Creek Timber Co & Missoula & 4190 & 0.5 & 2 & 20 & 1200 & 610 & 610 & A? \\
\hline MT & 40 & Lindbergh Lake & Flathead NF/Plum Creek Timber Co & Missoula & 4225 & 0.3 & 2 & 0 & 350 & 175 & 175 & $A C$ \\
\hline MT & 41 & Lindbergh Lake & Flathead NF/Private & Missoula & 4015 & 1.0 & 1 & 55 & 55 & 55 & 55 & C? \\
\hline MT & 42 & Lindbergh Lake & Flathead NF/Private & Missoula & 3995 & 1.9 & 1 & 55 & 55 & 55 & 55 & C? \\
\hline MT & 43 & Lindbergh Lake & Flathead National Forest & Missoula & 4280 & 0.2 & 9 & 0 & 150 & 39 & 25 & $\mathrm{~B}$ \\
\hline MT & 44 & Lindbergh Lake & Flathead National Forest & Missoula & 4215 & 1.1 & 12 & 0 & 340 & 185 & 250 & A \\
\hline MT & 45 & Lindbergh Lake & Flathead National Forest & Missoula & 4250 & 0.8 & 13 & 0 & 500 & 217 & 200 & A \\
\hline MT & 46 & Lindbergh Lake & Flathead National Forest & Missoula & 4230 & 1.8 & 5 & 0 & 50 & 24 & 25 & $\mathrm{C}$ \\
\hline MT & 47 & Lindbergh Lake & Flathead National Forest & Missoula & 4215 & 0.7 & 12 & 0 & 350 & 165 & 175 & A \\
\hline MT & 48 & Lindbergh Lake & Flathead National Forest & Missoula & 4215 & 0.4 & 12 & 0 & 250 & 101 & 75 & $\mathrm{~B}$ \\
\hline MT & 49 & Lindbergh Lake & Flathead NF/Private & Missoula & 4150 & 0.5 & 6 & 10 & 2000 & 843 & 625 & $A$ \\
\hline MT & 50 & Lindbergh Lake & Flathead NF/Private & Missoula & 4295 & 1.3 & 1 & 750 & 750 & 750 & 750 & A? \\
\hline MT & 51 & Lindbergh Lake & Flathead NF/Private & Missoula & 4425 & 0.1 & 2 & 20 & 120 & 70 & 70 & $\mathrm{BC}$ \\
\hline MT & 52 & Kraft Creek & Private & Missoula & 4010 & 1.8 & 2 & 20 & 200 & 110 & 110 & $\mathrm{AC}$ \\
\hline MT & 55 & Elk Creek & Flathead National Forest & Missoula & 3820 & 1.1 & 9 & 25 & 600 & 278 & 200 & $\mathrm{~A}$ \\
\hline MT & 56 & Lindbergh Lake & Flathead National Forest & Missoula & 4310 & 0.5 & 9 & 0 & 75 & 35 & 27 & C \\
\hline
\end{tabular}

Appendix A - 2 


\begin{tabular}{|c|c|c|c|c|c|c|c|c|c|c|c|c|}
\hline State & EO\# & Name & Ownership & County & Elevation (ft) & Size (ac) & Years visited & Min & Max & Mean & Median & Rank \\
\hline MT & 57 & Lost Creek-Cilly Creek Ponds & Flathead National Forest & Lake & 3190 & 1.2 & 9 & 0 & 25 & 5 & 0 & $\mathrm{D}$ \\
\hline MT & 58 & Salmon Prairie & Private & Lake & 3555 & 0.3 & 1 & 30 & 30 & 30 & 30 & C? \\
\hline MT & 59 & Shay Lake Pothole & Plum Creek Timber Company & Lake & 3560 & 0.2 & 2 & 0 & 50 & 25 & 25 & $\mathrm{C} ?$ \\
\hline MT & 60 & Shay Lake Pothole & Plum Creek Timber Company & Lake & 3540 & 0.6 & 2 & 20 & 50 & 35 & 35 & $C ?$ \\
\hline MT & 61 & Shay Lake Pothole & Flathead National Forest & Lake & 3580 & 0.2 & 9 & 0 & 200 & 91 & 150 & A \\
\hline MT & 62 & Shay Lake Pothole & Flathead National Forest & Lake & 3580 & 0.7 & 9 & 0 & 450 & 142 & 125 & A \\
\hline MT & 64 & Stoner Lake Pothole \#12 & Plum Creek Timber/Private & Missoula & 3960 & 0.8 & 2 & 100 & 100 & 100 & 100 & $\mathrm{BC}$ \\
\hline MT & 65 & Stoner Lake Pothole \#8 & Plum Creek Timber Company & Missoula & 3960 & 2.8 & 2 & 0 & 100 & 50 & 50 & $\mathrm{C} ?$ \\
\hline MT & 66 & Stoner Lake Pothole \#6 & Flathead NF/Plum Creek Timber Co & Missoula & 3940 & 1.0 & 2 & 50 & 50 & 50 & 50 & C? \\
\hline MT & 67 & Stoner Lake Pothole \#18 & Plum Creek Timber Company & Missoula & 3980 & 1.7 & 2 & 500 & 500 & 500 & 500 & $A ?$ \\
\hline MT & 68 & Stoner Lake Pothole \#20 & Plum Creek Timber Company & Missoula & 4000 & 0.4 & 2 & 50 & 50 & 50 & 50 & C? \\
\hline MT & 69 & Stoner Lake Pothole \#21 & Plum Creek Timber Company & Missoula & 4020 & 0.8 & 2 & 0 & 200 & 100 & 100 & $\mathrm{AC}$ \\
\hline MT & 70 & Condon Creek & $\begin{array}{c}\text { Flathead NF (Condon Creek } \\
\text { Botanical Area) }\end{array}$ & Missoula & 3760 & 0.3 & 9 & 0 & 300 & 109 & 112.5 & A \\
\hline MT & 72 & Owl Creek & Flathead National Forest & Missoula & 4320 & 0.3 & 9 & 75 & 3000 & 591 & 300 & A \\
\hline MT & 73 & Holland Lake Pond \#2 & Flathead National Forest & Missoula & 4160 & 0.5 & 9 & 0 & 300 & 155 & 100 & A \\
\hline MT & 74 & Holland Lake Pond \#3 & Flathead National Forest & Missoula & 4160 & 0.3 & 9 & 25 & 150 & 81 & 50 & $\mathrm{~B}$ \\
\hline MT & 75 & Holland Lake Pond \#4 & Flathead National Forest & Missoula & 4160 & 0.1 & 9 & 0 & 200 & 111 & 150 & $\mathrm{~B}$ \\
\hline MT & 76 & Holland Lake Pond \#5 & Flathead National Forest & Missoula & 4080 & 1.8 & 9 & 25 & 550 & 300 & 362.5 & A \\
\hline MT & 77 & Barber Creek & Flathead NF/Plum Creek Timber Co & Missoula & 4260 & 0.2 & 2 & 20 & 5000 & 2510 & 2510 & A? \\
\hline MT & 78 & Barber Creek & Flathead National Forest & Missoula & 4260 & 0.2 & 9 & 0 & 350 & 113 & 75 & $\mathrm{~B}$ \\
\hline MT & 79 & Holland Creek & Flathead National Forest & Missoula & 3960 & 0.4 & 9 & 0 & 1000 & 166 & 25 & $\mathrm{~B}$ \\
\hline MT & 80 & $\begin{array}{c}\text { Barber Creek Gravel Pit South } \\
\text { Pond \#2 }\end{array}$ & Flathead National Forest & Missoula & 3960 & 0.7 & 9 & 0 & 1000 & 133 & 25 & B \\
\hline MT & 81 & Holland Creek & Flathead National Forest & Missoula & 4080 & 0.9 & 9 & 20 & 450 & 233 & 300 & A \\
\hline MT & 82 & Holland Lake Pond \#6 & Flathead NF/Private & Missoula & 4100 & 3.6 & 2 & 20 & 200 & 110 & 110 & $\mathrm{AC}$ \\
\hline MT & 83 & Holland Lake Pond \#7 & Flathead NF/Private & Missoula & 4100 & 0.3 & 4 & 0 & 200 & 88 & 75 & $\mathrm{~B}$ \\
\hline MT & 84 & $\begin{array}{l}\text { Beaver Creek/Lindberg Lake } \\
\text { Road (East Pond) }\end{array}$ & Flathead National Forest & Missoula & 4020 & 0.3 & 9 & 0 & 750 & 145 & 75 & B \\
\hline MT & 87 & Elk Creek Pond 1-2 & Flathead National Forest & Missoula & 4020 & 0.2 & 9 & 25 & 1000 & 219 & 150 & A \\
\hline MT & 88 & Elk Creek Pond 1-3 & Flathead NF/Plum Creek Timber Co & Missoula & 3960 & 1.2 & 2 & 0 & 1000 & 500 & 500 & A? \\
\hline MT & 89 & Elk Creek Pond 1-4 & Flathead NF/Plum Creek Timber Co & Missoula & 4000 & 0.6 & 2 & 100 & 1000 & 550 & 550 & $A ?$ \\
\hline
\end{tabular}

Appendix A - 3 


\begin{tabular}{|c|c|c|c|c|c|c|c|c|c|c|c|c|}
\hline State & EO\# & Name & Ownership & County & Elevation (ft) & Size (ac) & Years visited & Min & Max & Mean & Median & Rank \\
\hline MT & 90 & Piper Creek Pond \#1 & Flathead National Forest & Lake & 3480 & 0.1 & 9 & 0 & 3000 & 414 & 150 & A \\
\hline MT & 91 & Piper Creek Pond \#2 & Flathead National Forest & Lake & 3520 & 0.4 & 9 & 0 & 2000 & 347 & 150 & A \\
\hline MT & 92 & Piper Creek Pond \#3 & Flathead National Forest & Lake & 3420 & 0.2 & 8 & 0 & 200 & 63 & 25 & $\mathrm{~B}$ \\
\hline MT & 93 & Piper Creek Pond \#4 & Flathead National Forest & Lake & 3320 & 0.2 & 8 & 0 & 1000 & 191 & 75 & $\mathrm{~B} ?$ \\
\hline MT & 94 & Piper Creek Pond \#5 & Flathead National Forest & Lake & 3520 & 0.6 & 9 & 0 & 300 & 175 & 200 & A \\
\hline MT & 95 & Piper Creek Pond \#6 & Flathead National Forest & Lake & 3540 & 0.4 & 9 & 0 & 200 & 56 & 25 & $\mathrm{BC}$ \\
\hline MT & 97 & Piper Creek Pond \#8 & Flathead National Forest & Lake & 3540 & 0.2 & 9 & 0 & 75 & 28 & 25 & $\mathrm{~B}$ \\
\hline MT & 98 & Piper Creek Pond \#9 & Flathead National Forest & Lake & 3540 & 0.0 & 9 & 25 & 300 & 128 & 150 & A \\
\hline MT & 99 & Piper Creek Pond \#10 & Flathead National Forest & Lake & 3520 & 0.3 & 9 & 0 & 1000 & 238 & 150 & $\mathrm{~A}$ \\
\hline MT & 100 & Piper Creek Pond \#11 & Flathead National Forest & Lake & 3580 & 0.2 & 9 & 0 & 2000 & 353 & 150 & A \\
\hline MT & 101 & Piper Creek Pond \#2 & Flathead National Forest & Lake & 3600 & 0.3 & 9 & 0 & 3000 & 478 & 150 & A \\
\hline MT & 102 & Condon Creek & Flathead National Forest & Missoula & 3720 & 0.9 & 8 & 10 & 225 & 86 & 50 & $\mathrm{~B}$ \\
\hline MT & 103 & Condon Creek & Flathead National Forest & Missoula & 3720 & 0.3 & 8 & 0 & 50 & 13 & 0 & $\mathrm{D}$ \\
\hline MT & 105 & Dog Creek & Flathead National Forest & Lake & 3700 & 2.6 & 1 & 50 & 50 & 50 & 50 & $\mathrm{C}$ ? \\
\hline MT & 106 & Holland Lake & Flathead National Forest & Missoula & 4000 & 0.4 & 7 & 0 & 150 & 89 & 150 & A \\
\hline MT & 107 & Pierce Creek & Flathead National Forest & Missoula & 4100 & 0.2 & 7 & 0 & 150 & 79 & 50 & B \\
\hline MT & 108 & $\begin{array}{c}\text { U-024 pond in Cilly Creek } \\
\text { Cluster }\end{array}$ & Flathead National Forest & Lake & 3230 & 2.0 & 7 & 0 & 650 & 343 & 400 & A \\
\hline MT & 109 & Pond U-084 & Flathead National Forest & Missoula & 4000 & 0.9 & 7 & 0 & 150 & 100 & 150 & $\mathrm{~B}$ \\
\hline MT & 110 & Pond north of Cygnet Lake & Flathead NF/Plum Creek Timber Co & Missoula & 4180 & 0.5 & 3 & 0 & 25 & 9 & 2 & D \\
\hline MT & 111 & Pond U-53 & Flathead National Forest & Missoula & 4020 & 0.3 & 7 & 0 & 75 & 36 & 25 & $\mathrm{~B}$ \\
\hline MT & 112 & Pond U-052 & Flathead National Forest & Missoula & 3799 & 0.3 & 7 & 0 & 450 & 221 & 275 & A \\
\hline MT & 113 & Pond U-073 & Flathead National Forest & Lake & 3540 & 0.2 & 6 & 0 & 150 & 58 & 50 & $\mathrm{C}$ \\
\hline MT & 114 & Was Pond U-32 & Flathead NF/Plum Creek Timber Co & Missoula & 4180 & 0.8 & 2 & 200 & 200 & 200 & 200 & $\mathrm{~B} ?$ \\
\hline MT & 115 & Whitetail Creek & Plum Creek Timber/MT DNRC & Lake & 3180 & 0.9 & 1 & 1500 & 1500 & 1500 & 1500 & A? \\
\hline MT & 116 & Porcupine Creek & Flathead NF/MT DNRC & Lake & 3200 & 0.3 & 1 & 1000 & 1000 & 1000 & 1000 & A? \\
\hline MT & 117 & Porcupine Creek & MT State DNRC & Lake & 3200 & 0.5 & 1 & 550 & 550 & 550 & 550 & A? \\
\hline MT & 118 & North of Cygnet Lake & Flathead National Forest & Missoula & 4250 & 0.5 & 1 & 10 & 10 & 10 & 10 & $\mathrm{D} ?$ \\
\hline MT & 121 & North of Cygnet Lake & Flathead NF/Private & Missoula & 4040 & 1.3 & 1 & -- & -- & -- & -- & $\mathrm{U}$ \\
\hline MT & 122 & North Side of Cygnet Lake & Plum Creek Timber Company & Missoula & 4010 & 1.0 & 1 & 14 & 14 & 14 & 14 & $\mathrm{D} ?$ \\
\hline
\end{tabular}

Appendix A - 4 


\begin{tabular}{|c|c|c|c|c|c|c|c|c|c|c|c|c|}
\hline State & EO\# & Name & Ownership & County & Elevation (ft) & Size (ac) & Years visited & Min & $\operatorname{Max}$ & Mean & Median & Rank \\
\hline MT & 123 & North of Cygnet Lake & Flathead NF/Plum Creek Timber Co & Missoula & 4180 & 0.5 & 1 & -- & -- & -- & -- & $U$ \\
\hline MT & 124 & North of Cygnet Lake & Flathead NF/Plum Creek Timber Co & Missoula & 4160 & 0.3 & 1 & -- & -- & -- & -- & $\mathrm{U}$ \\
\hline MT & 125 & North of Cygnet Lake & Flathead NF/Plum Creek Timber Co & Missoula & 4160 & 0.5 & 1 & 2000 & 2000 & 2000 & 2000 & A? \\
\hline MT & 126 & North of Cygnet Lake & Flathead NF/Plum Creek Timber Co & Missoula & 4180 & 0.4 & 1 & 13 & 13 & 13 & 13 & $\mathrm{D} ?$ \\
\hline MT & 127 & North of Cygnet Lake & Flathead National Forest & Missoula & 4000 & 0.9 & 1 & -- & -- & -- & -- & $U$ \\
\hline MT & 128 & North of Cygnet Lake & Flathead National Forest & Missoula & 4000 & 1.8 & 1 & -- & -- & -- & -- & $U$ \\
\hline MT & 129 & North of Cygnet Lake & Flathead National Forest & Missoula & 4040 & 0.8 & 1 & -- & -- & -- & -- & $U$ \\
\hline MT & 130 & $\begin{array}{l}\text { Road } 10161 \text { Pond (Transplant } \\
\text { Pond A) }\end{array}$ & Flathead National Forest & Lake & 3136 & 0.5 & 5 & 0 & 32 & 12 & 4 & $\mathrm{D}$ \\
\hline MT & 131 & Beaver Creek & Flathead National Forest & Missoula & 4232 & 0.6 & 2 & 0 & 25 & 13 & 12.5 & $\mathrm{D} ?$ \\
\hline MT & 135 & Falls Creek & Flathead NF/Plum Creek Timber Co & Missoula & 3690 & 0.5 & 1 & 50 & 50 & 50 & 50 & C? \\
\hline MT & 136 & Glacier Creek & Flathead National Forest & Missoula & 4225 & 0.2 & 1 & 75 & 75 & 75 & 75 & C? \\
\hline MT & 137 & Glacier Creek & Flathead National Forest & Missoula & 4360 & 0.2 & 1 & 250 & 250 & 250 & 250 & A? \\
\hline MT & 138 & Glacier Creek & Flathead National Forest & Missoula & 4331 & 0.7 & 1 & 5 & 5 & 5 & 5 & $\mathrm{D} ?$ \\
\hline MT & 139 & Glacier Creek & Flathead National Forest & Missoula & 4429 & 0.8 & 1 & 3 & 3 & 3 & 3 & $\mathrm{D} ?$ \\
\hline MT & 141 & Swan River State Forest & MT State DNRC & Lake & 3218 & 0.6 & 1 & 300 & 300 & 300 & 300 & A? \\
\hline OR & 8 & -- & Finley National Wildlife Refuge & Benton & -- & -- & 1 & -- & -- & -- & -- & $U$ \\
\hline WA & 1 & Dishman Hills Ponds & $\begin{array}{c}\text { Dishman Hills NRCA (State and } \\
\text { County?) }\end{array}$ & Spokane & -- & 0.5 & 2 & -- & -- & -- & -- & $u$ \\
\hline WA & 2 & Blackwater Islands RNA & Ridgefield National Wildlife Refuge & Clark & 10 & -- & 2 & -- & -- & -- & -- & $\mathrm{U}$ \\
\hline WA & 3 & Curtis Road 1 & $\begin{array}{c}\text { Private } \\
\end{array}$ & Spokane & 2300 & 1.0 & 1 & 500 & 500 & 500 & 500 & A? \\
\hline WA & 4 & Curtis Road 2 & Private & Spokane & 2320 & 0.5 & 1 & 500 & 500 & 500 & 500 & A? \\
\hline WA & 5 & Bretz Pothole & Private & Spokane & 2280 & -- & 2 & 500 & 500 & 500 & 500 & A? \\
\hline WA & 6 & Cameron Road & Private & Spokane & -- & 1.0 & 1 & -- & -- & -- & -- & $\mathrm{U}$ \\
\hline WA & 7 & Jennings Road & Private & Spokane & 2320 & 2.0 & 1 & -- & -- & -- & -- & $\mathrm{U}$ \\
\hline WA & 8 & Cross Tracks 1 & Private & Spokane & -- & 0.2 & 1 & -- & -- & -- & -- & $U$ \\
\hline WA & 9 & Cross Tracks 2 & Private & Spokane & -- & 0.5 & 1 & -- & -- & -- & -- & $U$ \\
\hline WA & 10 & Cross Tracks 3 & Private & Spokane & -- & -- & 1 & -- & -- & -- & -- & $U$ \\
\hline WA & 11 & East Findley lake & Turnbull National Wildlife Refuge & Spokane & 2300 & 4.0 & 4 & 0 & 402 & 137 & 10 & $\mathrm{~B}$ \\
\hline WA & 12 & Across from Kepple & $\begin{array}{c}\text { Private } \\
\end{array}$ & Spokane & 2320 & 2.0 & 1 & -- & -- & -- & -- & $\mathrm{U}$ \\
\hline WA & 15 & Lily Pond & Private & Spokane & 2300 & 0.25 & 1 & -- & -- & -- & -- & $\mathrm{U}$ \\
\hline WA & 16 & Anderson Road & Private & Spokane & -- & 1.0 & 1 & -- & -- & -- & -- & $\mathrm{U}$ \\
\hline
\end{tabular}

Appendix A - 5 


\begin{tabular}{|c|c|c|c|c|c|c|c|c|c|c|c|c|}
\hline State & EO\# & Name & Ownership & County & Elevation (ft) & Size (ac) & Years visited & Min & Max & Mean & Median & Rank \\
\hline WA & 17 & North of West Tritt Lake & Turnbull National Wildlife Refuge & Spokane & 2300 & 1.0 & 1 & -- & -- & -- & -- & $U$ \\
\hline WA & 18 & Pine Creek RNA South & Turnbull National Wildlife Refuge & Spokane & 2300 & 1.0 & 4 & 0 & 156 & 53 & 2 & $\mathrm{BC}$ \\
\hline WA & 19 & North Fee Station & Turnbull National Wildlife Refuge & Spokane & 2250 & 1.0 & 2 & -- & -- & -- & -- & $\mathrm{D} ?$ \\
\hline WA & 20 & Turnbull Pond 85 & Turnbull National Wildlife Refuge & Spokane & 2300 & -- & 3 & 0 & 57 & 20 & 3 & $\mathrm{C}$ \\
\hline WA & 21 & Turnbull Pond 21A & Turnbull National Wildlife Refuge & Spokane & 2300 & -- & 3 & 0 & 1 & 1 & 0.5 & $\mathrm{D} ?$ \\
\hline WA & 22 & Turnbull Pond 77 & Turnbull National Wildlife Refuge & Spokane & 2300 & -- & 2 & -- & -- & -- & -- & $\mathrm{D} ?$ \\
\hline WA & 23 & Turnbull Pond 72 & Turnbull National Wildlife Refuge & Spokane & 2300 & -- & 1 & 2 & 2 & 2 & 2 & $\mathrm{D} ?$ \\
\hline WA & 24 & Turnbull Pond 55 & Turnbull National Wildlife Refuge & Spokane & 2300 & -- & 2 & 2 & 150 & 76 & 76 & C? \\
\hline WA & 25 & Turnbull Pond 39 & Turnbull National Wildlife Refuge & Spokane & 2300 & -- & 1 & 3 & 3 & 3 & 3 & $\mathrm{D} ?$ \\
\hline WA & 26 & Turnbull Pond 21C & Turnbull National Wildlife Refuge & Spokane & 2300 & -- & 1 & 0 & 0 & -- & $--!$ & $\mathrm{U}$ \\
\hline WA & 28 & Turnbull Pond 61 & Turnbull National Wildlife Refuge & Spokane & 2300 & -- & 3 & 46 & 75 & 61 & 60.5 & $\mathrm{C}$ \\
\hline WA & 29 & Turnbull Pond 1B & Turnbull National Wildlife Refuge & Spokane & 2300 & -- & 1 & 1 & 1 & 1 & 1 & $\mathrm{D} ?$ \\
\hline WA & 30 & Tunbull Pond 21B & Turnbull National Wildlife Refuge & Spokane & 2300 & -- & 1 & 5 & 5 & 5 & 5 & $\mathrm{D} ?$ \\
\hline WA & 31 & Turnbull Pond 31 & Turnbull National Wildlife Refuge & Spokane & 2300 & -- & 2 & 0 & 3 & 2 & 1.5 & $\mathrm{D} ?$ \\
\hline WA & 32 & Turnbull Pond 29 & Turnbull National Wildlife Refuge & Spokane & 2280 & 1.0 & 3 & 2 & 75 & 32 & 18 & $\mathrm{C}$ \\
\hline WA & 33 & Turnbull Pond 12 & Turnbull National Wildlife Refuge & Spokane & 2300 & -- & 2 & -- & -- & -- & -- & $\mathrm{D} ?$ \\
\hline WA & 34 & Tunbull Pond $1 \mathrm{~A}$ & Turnbull National Wildlife Refuge & Spokane & 2330 & -- & 1 & 1 & 1 & 1 & 1 & $\mathrm{D} ?$ \\
\hline WA & 35 & Turnbull Pond 112 & Turnbull National Wildlife Refuge & Spokane & 2300 & -- & 1 & 3 & 3 & 3 & 3 & $\mathrm{D} ?$ \\
\hline WA & 36 & Turnbull Pond 96 & Turnbull National Wildlife Refuge & Spokane & 2300 & -- & 3 & 0 & 15 & 8 & 7.5 & $\mathrm{D} ?$ \\
\hline WA & 37 & Hog Lake NW & Bureau of Land Management & Spokane & 2180 & 5.0 & 1 & 50 & 50 & 50 & 50 & $C ?$ \\
\hline WA & 38 & Turnbull Pond 107 & Turnbull National Wildlife Refuge & Spokane & 2300 & -- & 2 & 2 & 30 & 16 & 16 & $\mathrm{D} ?$ \\
\hline WA & 39 & Foot Wetland & Fort Lewis & Pierce & 320 & 20.0 & 8 & 20 & 655 & 379 & 331.5 & A \\
\hline WA & 40 & South Bentsen & Fort Lewis & Pierce & 340 & -- & 8 & 0 & 100 & 17 & 0 & $\mathrm{C}$ \\
\hline WA & 41 & Bentsen Wetland & Fort Lewis/McCord Air Force Base & Pierce & 320 & 1.0 & 8 & 0 & 8200 & 1847 & 729 & A \\
\hline WA & 42 & Binocular Pond & Fort Lewis & Pierce & 320 & -- & 9 & 6 & 90 & 42 & 27.5 & $\mathrm{~B}$ \\
\hline WA & 43 & Shaver Kettle & Fort Lewis & Pierce & 330 & 0.2 & 8 & 120 & 3750 & 1178 & 800 & A \\
\hline WA & 44 & Trench Wetland & Fort Lewis & Pierce & 330 & 0.5 & 8 & 20 & 300 & 177 & 205 & A \\
\hline WA & 45 & NE Chamber Satellite & Fort Lewis & Pierce & 315 & 0.2 & 8 & 0 & 72 & 26 & 11.5 & $\mathrm{C}$ \\
\hline WA & 46 & North Chambers & Fort Lewis & Pierce & 315 & 5.0 & 9 & 325 & 2240 & 768 & 470 & $\mathrm{~A}$ \\
\hline WA & 47 & West Shaver Pond & Fort Lewis & Pierce & 315 & 2.5 & 9 & 375 & 822 & 667 & 785 & $A$ \\
\hline WA & 48 & Crone Marsh & Fort Lewis & Pierce & 340 & 40.0 & 9 & 920 & 12275 & 4182 & 2427.5 & A \\
\hline WA & 49 & Joseph Marsh & Fort Lewis & Pierce & 350 & 10.0 & 7 & 42 & 1127 & 445 & 300 & A \\
\hline WA & 50 & Middle East Chambers & Fort Lewis & Pierce & 320 & 0.5 & 8 & 6 & 104 & 35 & 18.5 & $\mathrm{~B}$ \\
\hline WA & 51 & Dailman Lake & Fort Lewis & Pierce & 320 & 40.0 & 8 & 39 & 565 & 300 & 312 & $A$ \\
\hline
\end{tabular}

Appendix A - 6 


\begin{tabular}{|c|c|c|c|c|c|c|c|c|c|c|c|c|}
\hline State & EO\# & Name & Ownership & County & Elevation (ft) & Size (ac) & Years visited & Min & Max & Mean & Median & Rank \\
\hline WA & 52 & Hamilton Lake & Fort Lewis & Pierce & 320 & 8.0 & 8 & 0 & 30 & 16 & 13 & $\mathrm{C}$ \\
\hline WA & 53 & Chambers East & Fort Lewis & Pierce & 320 & 1.0 & 8 & 22 & 1038 & 286 & 113.5 & $A$ \\
\hline WA & 54 & Turnbull Pond 13 & Turnbull National Wildlife Refuge & Spokane & 2300 & -- & 1 & 9 & 9 & 9 & 9 & $\mathrm{D} ?$ \\
\hline WA & 55 & Turnbull Pond 82 & Turnbull National Wildlife Refuge & Spokane & 2300 & -- & 1 & 1 & 1 & 1 & 1 & $\mathrm{D} ?$ \\
\hline WA & 56 & Turnbull Pond 63 & Turnbull National Wildlife Refuge & Spokane & 2300 & -- & 2 & 0 & 3 & 2 & 1.5 & $\mathrm{D} ?$ \\
\hline WA & 57 & Turnbull Pond 32 & Turnbull National Wildlife Refuge & Spokane & 2300 & -- & 3 & 0 & 39 & 13 & 1 & $\mathrm{D}$ \\
\hline WA & 59 & Turnbull Pond 139 & Turnbull National Wildlife Refuge & Spokane & 2300 & -- & 2 & 1 & 9 & 5 & 5 & $\mathrm{D} ?$ \\
\hline WA & 60 & Turnbull Pond 117 & Turnbull National Wildlife Refuge & Spokane & 2300 & -- & 1 & 3 & 3 & 3 & 3 & $\mathrm{D} ?$ \\
\hline WA & 61 & Turnbull Pond 18 & Turnbull National Wildlife Refuge & Spokane & 2300 & -- & 3 & 1 & 10 & 5 & 3 & $\mathrm{D}$ \\
\hline WA & 62 & Turnbull Pond 149 & Turnbull National Wildlife Refuge & Spokane & 2300 & -- & 2 & 0 & 111 & 56 & 55.5 & $\mathrm{BD}$ \\
\hline WA & 63 & Turnbull Pond 150 & Turnbull National Wildlife Refuge & Spokane & 2300 & -- & 1 & 76 & 76 & 76 & 76 & $\mathrm{C} ?$ \\
\hline WA & 64 & Powder Factory & Private & Thurston & 220 & -- & 1 & -- & -- & -- & -- & $\mathrm{U}$ \\
\hline WA & 65 & Campbell Lake NW & Private & Spokane & 2340 & -- & 1 & 7 & 7 & 7 & 7 & $\mathrm{D} ?$ \\
\hline WA & 67 & Smythe Road North & WA State DNR & Spokane & 2380 & -- & 1 & 1500 & 1500 & 1500 & 1500 & $A ?$ \\
\hline WA & 68 & Burnett Road & WA State DNR & Spokane & 2400 & 6.5 & 1 & 1500 & 1500 & 1500 & 1500 & $A ?$ \\
\hline WA & -- & Training area 11 & Fort Lewis & Pierce & -- & -- & 1 & -- & -- & -- & -- & $U$ \\
\hline
\end{tabular}

Appendix A - 7 


\section{APPENDIX B. ANNUAL HoWELlia AQUATILIS SURVEY DATA BY STATE AND ELEMENT OCCURRENCE NUMBER}


Appendix B. Annual Howellia aquatilis population estimates/counts by state and Element Occurrence number. Only includes occurrences presumed to be extant. Data are compiled from individual state Natural Heritage Programs, the Flathead National Forest's annual monitoring data and the Land

Trend Analysis Program at Fort Lewis, WA. Numerical values for Montana populations surveyed as part of the Flathead National Forest's monitoring plan are derived from estimates of individuals in sampling quadrats. Quadrats are assigned a value of $0=$ no plants found, Low $=1$ to 50 plants,

Moderate $=50-100$ plants or High $=>100$ plants. Final quantitative estimates for this assessment were derived by assigning numerical values of 25 , 75 and 150 for Low, Medium and High respectively and adding those numbers together to come up with a final population estimate for that year. In some cases, the midpoint of an estimated population range is provided.

“-1" = Site visit in which no quantitative survey data exists or was not available for this assessment. However, water howellia was observed during a visit that year and a qualitative measure of abundance might exist.

"0" = Site visit in which no water howellia was observed that year.

\begin{tabular}{|c|c|c|c|c|c|c|c|c|c|c|c|c|c|c|c|c|c|c|c|c|c|c|c|c|c|c|c|}
\hline State & EO\# & 1967 & 1978 & 1980 & 1982 & 1983 & 1984 & 1985 & 1986 & 1987 & 1988 & 1989 & 1990 & 1991 & 1992 & 1993 & 1994 & 1995 & 1996 & 1997 & 1998 & 1999 & 2000 & 2001 & 2002 & 2003 & 2004 \\
\hline CA & 1 & & & & & & & & & & & & & & & & & & 75 & 200 & & & & & & & \\
\hline $\mathrm{CA}$ & 2 & & & & & & & & & & & & & & & & & & 25 & & & & & & & & \\
\hline CA & 3 & & & & & & & & & & & & & & & & & & 25 & & & & & 30 & & & \\
\hline CA & 4 & & & & & & & & & & & & & & & & & & 200 & 2000 & & & & & & & \\
\hline CA & 5 & & & & & & & & & & & & & & & & & & 10 & & & & 10 & & & & \\
\hline $\mathrm{CA}$ & 6 & & & & & & & & & & & & & & & & & & & & -1 & -1 & & & & & \\
\hline ID & 1 & -1 & & & & & & & & & 30 & & & & & & & 50 & 100 & & & 300 & -1 & 3000 & -1 & -1 & -1 \\
\hline MT & 1 & & & & & & 500 & & & 85 & & 350 & 27 & 25 & & & & & & 2 & 50 & 0 & 100 & 300 & 75 & 25 & 200 \\
\hline MT & 2 & & & & & & 6500 & & & 2500 & & & & & & & & & & -1 & & & & & & & \\
\hline MT & 3 & & & & & 5000 & & & & & & & & & & & & & & 10 & & & & & & & \\
\hline MT & 4 & & -1 & & -1 & 30 & & & & & & & & & & & & & & 0 & & & & & & & \\
\hline MT & 5 & & & & & & & 5000 & & 5000 & -1 & -1 & -1 & -1 & -1 & -1 & -1 & -1 & & 0 & & & & & & & \\
\hline MT & 6 & & & & & & & & 2000 & 2000 & & 1500 & 750 & 900 & & & & & & -1 & 25 & 50 & 450 & & 450 & 225 & 350 \\
\hline MT & 7 & & & & & & & & & 3500 & & 1500 & 550 & 1500 & & & & & & 50 & 50 & 300 & 300 & 300 & 300 & 50 & 300 \\
\hline MT & 8 & & & & & & & & & 2500 & -1 & 1200 & 40 & 1500 & -1 & & 0 & -1 & -1 & -1 & 50 & 300 & 300 & 300 & 50 & 50 & 25 \\
\hline MT & 9 & & & & & & & & & 550 & -1 & 750 & 220 & 40 & & & & & & -1 & 0 & 150 & 175 & 75 & 225 & 0 & 75 \\
\hline MT & 10 & & & & & & & & & 250 & & & & & & & & & & -1 & 0 & 75 & 150 & 25 & 50 & 0 & 0 \\
\hline MT & 11 & & & & & & & & & 150 & & & & & & & & & & -1 & & & & & & & \\
\hline MT & 12 & & & & & & & & & 450 & & 16 & 35 & 260 & & & & & & -1 & 25 & & 225 & 50 & 0 & 0 & 75 \\
\hline MT & 13 & & & & & & & & & 1200 & -1 & 600 & 33 & 310 & & & & & & -1 & 25 & 300 & 225 & 300 & 175 & 0 & 150 \\
\hline MT & 14 & & & & & & & & & 350 & & 500 & 200 & 90 & & & & & & -1 & 0 & 150 & 150 & 150 & 50 & 0 & 150 \\
\hline MT & 15 & & & & & & & & & 300 & & & & & & & & & & 50 & 0 & 150 & 150 & 150 & 150 & 0 & 150 \\
\hline MT & 16 & & & & & & & & & 400 & & 1200 & 400 & 70 & & & & & & 50 & 0 & 300 & 300 & 300 & 300 & 100 & 300 \\
\hline
\end{tabular}

Appendix $B-1$ 


\begin{tabular}{|c|c|c|c|c|c|c|c|c|c|c|c|c|c|c|c|c|c|c|c|c|c|c|c|c|c|c|c|}
\hline State & EO\# & 1967 & 1978 & 1980 & 1982 & 1983 & 1984 & 1985 & 1986 & 1987 & 1988 & 1989 & 1990 & 1991 & 1992 & 1993 & 1994 & 1995 & 1996 & 1997 & 1998 & 1999 & 2000 & 2001 & 2002 & 2003 & 2004 \\
\hline MT & 17 & & & & & & & & & 11 & & 15 & 0 & 0 & & & & & & 0 & & & & & & & \\
\hline MT & 18 & & & & & & & & & 200 & & & & & & & & & & -1 & 25 & 25 & 450 & 450 & 450 & 0 & 325 \\
\hline MT & 19 & & & & & & & & & 175 & & & & & & & & & & 0 & 25 & 0 & 825 & 750 & 900 & 325 & 700 \\
\hline MT & 20 & & & & & & & & 5000 & 1000 & -1 & 1250 & 190 & 210 & -1 & & 0 & -1 & -1 & -1 & 50 & 175 & 300 & 225 & 50 & 50 & 300 \\
\hline MT & 21 & & & & & & & & -1 & 50 & & & & & & & & & & 0 & & & & & & & \\
\hline MT & 22 & & & & & & & & & 200 & & 750 & 80 & 100 & & & & & & 0 & 25 & 25 & 150 & 150 & 150 & 150 & 150 \\
\hline MT & 23 & & & & & & & & 300 & 3 & & 450 & 20 & 110 & & & & & & -1 & 0 & 25 & 150 & 150 & 150 & 150 & 150 \\
\hline MT & 24 & & & & & & & & & 30 & & & & & & & & & & 0 & 25 & 25 & 25 & 75 & 25 & 25 & 150 \\
\hline MT & 25 & & & & & & & & & 25 & & 110 & 0 & 15 & & & & & & 0 & 0 & 0 & 225 & 325 & 200 & 25 & 325 \\
\hline MT & 26 & & & & & & & & & 250 & & 700 & 1200 & 1500 & & & & & & -1 & 25 & 300 & 300 & 175 & 200 & 50 & 200 \\
\hline MT & 27 & & & & & & & & & 300 & -1 & 350 & 200 & 195 & -1 & & 0 & -1 & -1 & -1 & 0 & 25 & 225 & 325 & 300 & 325 & 450 \\
\hline MT & 28 & & & & & & & & & 225 & & & & & & & & & & 0 & 0 & 0 & & & & & \\
\hline MT & 29 & & & & & & & & & 250 & & 650 & 150 & 165 & & & & & & -1 & 0 & 0 & & & & & \\
\hline MT & 30 & & & & & & & & & 1000 & & 1000 & 0 & 15 & & & & & & -1 & & & & & & & \\
\hline MT & 31 & & & & & & & & & 160 & & & & & & & & & & 0 & 0 & 0 & & & & & \\
\hline MT & 32 & & & & & 800 & & & & & & 900 & 5 & 25 & & & & & & 30 & & & & & & & \\
\hline MT & 33 & & & & & 50 & & & & & & & & & & & & & & -1 & & & & & & & \\
\hline MT & 34 & & & & & 60 & & & & & & & & & & & & & & -1 & & & & & & & \\
\hline MT & 35 & & & & & 500 & & & & & & 600 & 0 & 15 & & & & & & 50 & & & & & & & \\
\hline MT & 36 & & & & & & & & & 120 & & & & & & & & & & 20 & & & & & & & \\
\hline MT & 37 & & & & & & & & & 12 & & & & & & & & & & -1 & 100 & 50 & 375 & 300 & 225 & & 0 \\
\hline MT & 38 & & & & & & & & & 1100 & & & & & & & & & & 2 & & & & & & & \\
\hline MT & 39 & & & & & & & & & 1200 & & & & & & & & & & 20 & & & & & & & \\
\hline MT & 40 & & & & & & & & & 350 & & & & & & & & & & 0 & & & & & & & \\
\hline MT & 41 & & & & & & & & & 55 & & & & & & & & & & & & & & & & & \\
\hline MT & 42 & & & & & & & & & 55 & & & & & & & & & & & & & & & & & \\
\hline MT & 43 & & & & & & & & & 22 & & & & & & & & & & 0 & 0 & 25 & 75 & 25 & 50 & 0 & 150 \\
\hline MT & 44 & & & & & & & & & 340 & & 105 & 0 & 0 & & & & & & 3 & 25 & 300 & 300 & 325 & 200 & 300 & 325 \\
\hline MT & 45 & & & & & & & & & 300 & & 350 & 10 & 500 & & & 10 & & & 50 & 75 & 200 & 250 & 450 & 175 & 0 & 450 \\
\hline MT & 46 & & & & & & & & & 50 & & 40 & 3 & 25 & & & & & & 0 & & & & & & & \\
\hline MT & 47 & & & & & & & & & 200 & & 250 & 150 & 200 & & & & & & 0 & 25 & 50 & 100 & 250 & 350 & 50 & 350 \\
\hline MT & 48 & & & & & & & & & 250 & & 200 & 0 & 20 & & & & & & 20 & 50 & 50 & 175 & 100 & 150 & 25 & 175 \\
\hline MT & 49 & & & & & & & & & 1750 & & 2000 & 250 & 1000 & & & 10 & & & 50 & & & & & & & \\
\hline MT & 50 & & & & & & & & & 750 & & & & & & & & & & & & & & & & & \\
\hline
\end{tabular}

Appendix B - 2 


\begin{tabular}{|c|c|c|c|c|c|c|c|c|c|c|c|c|c|c|c|c|c|c|c|c|c|c|c|c|c|c|c|}
\hline State & EO\# & 1967 & 1978 & 1980 & 1982 & 1983 & 1984 & 1985 & 1986 & 1987 & 1988 & 1989 & 1990 & 1991 & 1992 & 1993 & 1994 & 1995 & 1996 & 1997 & 1998 & 1999 & 2000 & 2001 & 2002 & 2003 & 2004 \\
\hline MT & 51 & & & & & & & & & 120 & & & & & & & & & & 20 & & & & & & & \\
\hline MT & 52 & & & & & & & & & 200 & & & & & & & & & & 20 & & & & & & & \\
\hline MT & 53 & & & & & & & & & & 250 & & & & & & & & & -1 & & & & & & & \\
\hline MT & 54 & & & & & & & & & & 450 & & & & & & & & & 50 & 525 & 900 & & & & & \\
\hline MT & 55 & & & & & & & & & & 100 & & & & & & & & & -1 & 25 & 250 & 150 & 450 & 600 & 50 & 600 \\
\hline MT & 56 & & & & & & & & & & & 27 & & & & & & & & 10 & 0 & 0 & 75 & 75 & 50 & 25 & 50 \\
\hline MT & 57 & & & & & & & & & & & 22 & & & & & & & & 0 & 0 & 0 & 0 & 0 & 0 & 25 & 0 \\
\hline MT & 58 & & & & & & & & & & & & 30 & & & & & & & & & & & & & & \\
\hline MT & 59 & & & & & & & & & & & & & & & & & 50 & & 0 & & & & & & & \\
\hline MT & 60 & & & & & & & & & & & & & & & & & 50 & & 20 & & & & & & & \\
\hline MT & 61 & & & & & & & & & & & & & & & & & 200 & & 20 & 0 & 0 & 150 & 150 & 150 & 0 & 150 \\
\hline MT & 62 & & & & & & & & & & & & & & & & & 100 & & 0 & 0 & 250 & 125 & 150 & 200 & 0 & 450 \\
\hline MT & 63 & & & & & & & & & & & & & & & & & 300 & & 0 & & & & & & & \\
\hline MT & 64 & & & & & & & & & & & & & & & & & 100 & & -1 & & & & & & & \\
\hline MT & 65 & & & & & & & & & & & & & & & & & 100 & & 0 & & & & & & & \\
\hline MT & 66 & & & & & & & & & & & & & & & & & 50 & & -1 & & & & & & & \\
\hline MT & 67 & & & & & & & & & & & & & & & & & 500 & & -1 & & & & & & & \\
\hline MT & 68 & & & & & & & & & & & & & & & & & 50 & & 50 & & & & & & & \\
\hline MT & 69 & & & & & & & & & & & & & & & & & 200 & & 0 & & & & & & & \\
\hline MT & 70 & & & & & & & & & & & & & & & & & 300 & & -1 & 0 & 25 & 150 & 75 & 150 & 25 & 150 \\
\hline MT & 71 & & & & & & & & & & & & & & & & & 300 & & 10 & 25 & 150 & 150 & 150 & 150 & 150 & 25 \\
\hline MT & 72 & & & & & & & & & & & & & & & & & 3000 & & -1 & 150 & 300 & 300 & 300 & 75 & 300 & 300 \\
\hline MT & 73 & & & & & & & & & & & & & & & & & 100 & & 20 & 0 & 25 & 300 & 300 & 300 & 300 & 50 \\
\hline MT & 74 & & & & & & & & & & & & & & & & & 50 & & -1 & 25 & 25 & 150 & 150 & 50 & 150 & 50 \\
\hline MT & 75 & & & & & & & & & & & & & & & & & 200 & & 20 & 25 & 150 & 150 & 150 & 150 & 0 & 150 \\
\hline MT & 76 & & & & & & & & & & & & & & & & & 300 & & -1 & 25 & 50 & 475 & 450 & 425 & 125 & 550 \\
\hline MT & 77 & & & & & & & & & & & & & & & & & 5000 & & 20 & & & & & & & \\
\hline MT & 78 & & & & & & & & & & & & & & & & & 350 & & -1 & 0 & 75 & 75 & 75 & 150 & 25 & 150 \\
\hline MT & 79 & & & & & & & & & & & & & & & & & 1000 & & -1 & 0 & 75 & 25 & 25 & 25 & 25 & 150 \\
\hline MT & 80 & & & & & & & & & & & & & & & & & 1000 & & 0 & 0 & 25 & 25 & 50 & 25 & 50 & 25 \\
\hline MT & 81 & & & & & & & & & & & & & & & & & 200 & & 20 & 25 & 300 & 300 & 325 & 300 & 450 & 175 \\
\hline MT & 82 & & & & & & & & & & & & & & & & & 200 & & 20 & & & & & & & \\
\hline MT & 83 & & & & & & & & & & & & & & & & & 200 & & 0 & 0 & 150 & & & & & \\
\hline MT & 84 & & & & & & & & & & & & & & & & & 750 & & 1 & 75 & 150 & 150 & 75 & 50 & 0 & 50 \\
\hline
\end{tabular}

Appendix B - 3 


\begin{tabular}{|c|c|c|c|c|c|c|c|c|c|c|c|c|c|c|c|c|c|c|c|c|c|c|c|c|c|c|c|}
\hline State & EO\# & 1967 & 1978 & 1980 & 1982 & 1983 & 1984 & 1985 & 1986 & 1987 & 1988 & 1989 & 1990 & 1991 & 1992 & 1993 & 1994 & 1995 & 1996 & 1997 & 1998 & 1999 & 2000 & 2001 & 2002 & 2003 & 2004 \\
\hline MT & 85 & & & & & & & & & & & & & & & & & -1 & & -1 & & & & & & & \\
\hline MT & 86 & & & & & & & & & & & & & & & & & 1000 & & 20 & 100 & 300 & 225 & 175 & 300 & 300 & 300 \\
\hline MT & 87 & & & & & & & & & & & & & & & & & 1000 & & 50 & 25 & 150 & 150 & 150 & 150 & 150 & 150 \\
\hline MT & 88 & & & & & & & & & & & & & & & & & 1000 & & 0 & & & & & & & \\
\hline MT & 89 & & & & & & & & & & & & & & & & & 1000 & & 100 & & & & & & & \\
\hline MT & 90 & & & & & & & & & & & & & & & & & 3000 & & 0 & 25 & 75 & 150 & 150 & 150 & 25 & 150 \\
\hline MT & 91 & & & & & & & & & & & & & & & & & 2000 & & -1 & 25 & 150 & 150 & 150 & 150 & 0 & 150 \\
\hline MT & 92 & & & & & & & & & & & & & & & & & 200 & & 0 & 25 & 25 & 75 & 150 & 25 & & 0 \\
\hline MT & 93 & & & & & & & & & & & & & & & & & 1000 & & 50 & 25 & 75 & 75 & 150 & 150 & & 0 \\
\hline MT & 94 & & & & & & & & & & & & & & & & & 300 & & 0 & 0 & 300 & 300 & 150 & 300 & 25 & 200 \\
\hline MT & 95 & & & & & & & & & & & & & & & & & 200 & & 0 & 25 & 25 & 75 & 0 & 0 & 25 & 150 \\
\hline MT & 96 & & & & & & & & & & & & & & & & & 24 & & 0 & 0 & 0 & 150 & 100 & 300 & 0 & 300 \\
\hline MT & 97 & & & & & & & & & & & & & & & & & 24 & & 0 & 0 & 25 & 25 & 75 & 50 & 0 & 50 \\
\hline MT & 98 & & & & & & & & & & & & & & & & & 300 & & -1 & 25 & 150 & 75 & 150 & 150 & 25 & 150 \\
\hline MT & 99 & & & & & & & & & & & & & & & & & 1000 & & -1 & 150 & 150 & 150 & 150 & 150 & 0 & 150 \\
\hline MT & 100 & & & & & & & & & & & & & & & & & 2000 & & -1 & 75 & 150 & 150 & 150 & 150 & 0 & 150 \\
\hline MT & 101 & & & & & & & & & & & & & & & & & 3000 & & -1 & 75 & 150 & 150 & 150 & 150 & 0 & 150 \\
\hline MT & 102 & & & & & & & & & & & & & & & & & & & 10 & 25 & 25 & 50 & 50 & 100 & 200 & 225 \\
\hline MT & 103 & & & & & & & & & & & & & & & & & & & 50 & 0 & 0 & 0 & 0 & 0 & 50 & 0 \\
\hline MT & 104 & & & & & & & & & & & & & & & & & & & 100 & 50 & 450 & 450 & 450 & 450 & 200 & 350 \\
\hline MT & 105 & & & & & & & & & & & & & & & & & & & 50 & & & & & & & \\
\hline MT & 106 & & & & & & & & & & & & & & & & & & & & 25 & 0 & 0 & 150 & 150 & 150 & 150 \\
\hline MT & 107 & & & & & & & & & & & & & & & & & & & & 25 & 150 & 150 & 25 & 150 & 0 & 50 \\
\hline MT & 108 & & & & & & & & & & & & & & & & & & & & 0 & 525 & 650 & 375 & 425 & 25 & 400 \\
\hline MT & 109 & & & & & & & & & & & & & & & & & & & & 0 & 25 & 150 & 150 & 75 & 150 & 150 \\
\hline MT & 110 & & & & & & & & & & & & & & & & & & & & & & 2 & & 25 & & 0 \\
\hline MT & 111 & & & & & & & & & & & & & & & & & & & & 0 & 50 & 75 & 75 & 25 & 0 & 25 \\
\hline MT & 112 & & & & & & & & & & & & & & & & & & & & 0 & 275 & 450 & 75 & 350 & 0 & 400 \\
\hline MT & 113 & & & & & & & & & & & & & & & & & & & & 0 & 75 & 25 & 75 & & 25 & 150 \\
\hline MT & 114 & & & & & & & & & & & & & & & & & & & & & 200 & -1 & & & & \\
\hline MT & 115 & & & & & & & & & & & & & & & & & & & & & & 1500 & & & & \\
\hline MT & 116 & & & & & & & & & & & & & & & & & & & & & & 1000 & & & & \\
\hline MT & 117 & & & & & & & & & & & & & & & & & & & & & & 550 & & & & \\
\hline MT & 118 & & & & & & & & & & & & & & & & & & & & & & 10 & & & & \\
\hline
\end{tabular}

Appendix B - 4 


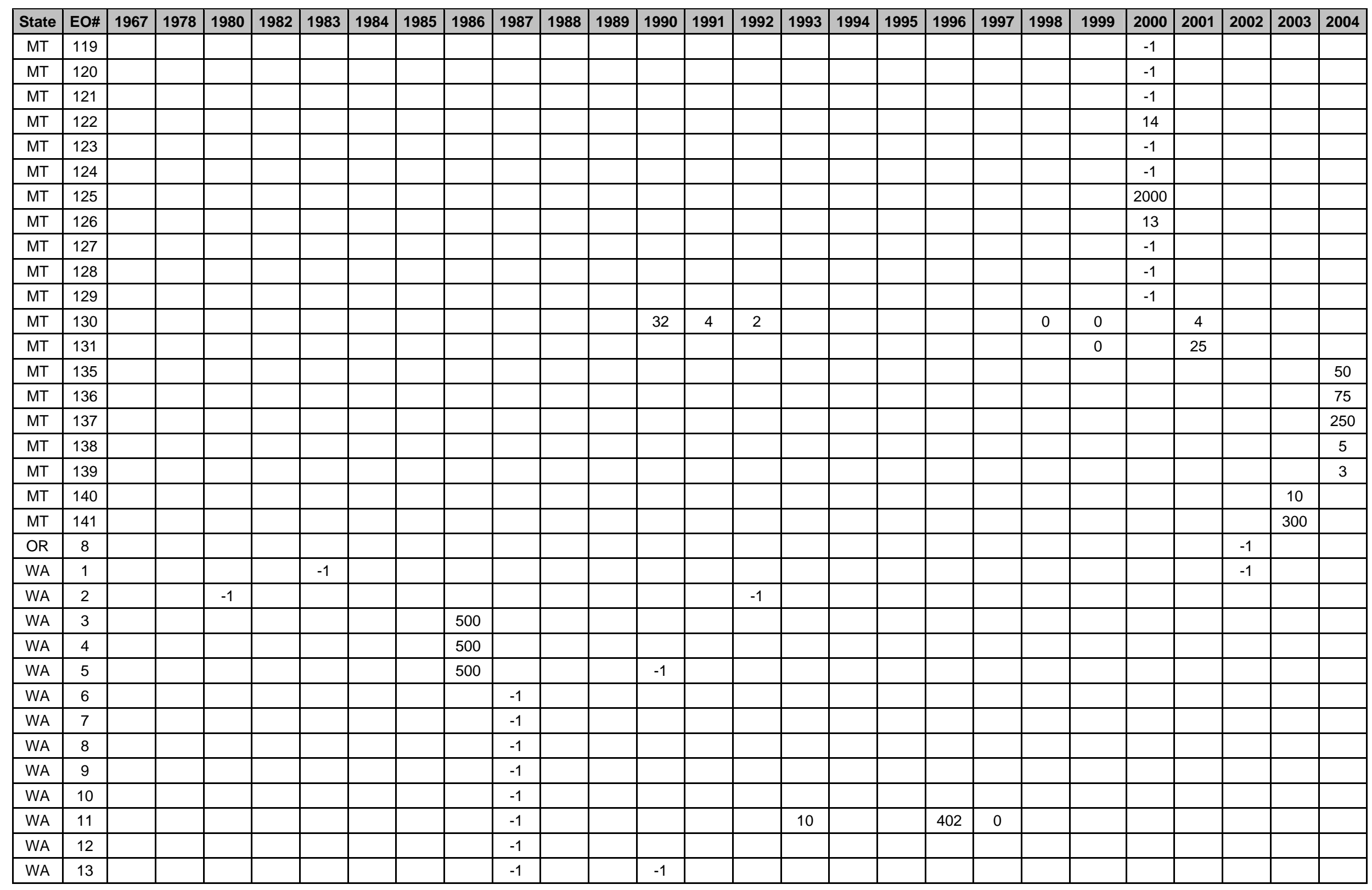

Appendix B - 5 


\begin{tabular}{|c|c|c|c|c|c|c|c|c|c|c|c|c|c|c|c|c|c|c|c|c|c|c|c|c|c|c|c|}
\hline State & EO\# & 1967 & 1978 & 1980 & 1982 & 1983 & 1984 & 1985 & 1986 & 1987 & 1988 & 1989 & 1990 & 1991 & 1992 & 1993 & 1994 & 1995 & 1996 & 1997 & 1998 & 1999 & 2000 & 2001 & 2002 & 2003 & 2004 \\
\hline WA & 14 & & & & & & & & & -1 & & & & & & & & & -1 & & & & & & & & \\
\hline WA & 15 & & & & & & & & & -1 & & & & & & & & & & & & & & & & & \\
\hline WA & 16 & & & & & & & & & -1 & & & & & & & & & & & & & & & & & \\
\hline WA & 17 & & & & & & & & & & & & -1 & & & & & & & & & & & & & & \\
\hline WA & 18 & & & & & & & & & & & & -1 & & & 2 & & & 156 & 0 & & & & & & & \\
\hline WA & 19 & & & & & & & & & & & & -1 & & & & & & & 0 & & & & & & & \\
\hline WA & 20 & & & & & & & & & & & & & & & 3 & & & 57 & 0 & & & & & & & \\
\hline WA & 21 & & & & & & & & & & & & & & & -1 & & & 1 & 0 & & & & & & & \\
\hline WA & 22 & & & & & & & & & & & & & & & -1 & & & & 0 & & & & & & & \\
\hline WA & 23 & & & & & & & & & & & & & & & 2 & & & & & & & & & & & \\
\hline WA & 24 & & & & & & & & & & & & & & & 2 & & & 150 & & & & & & & & \\
\hline WA & 25 & & & & & & & & & & & & & & & 3 & & & & & & & & & & & \\
\hline WA & 26 & & & & & & & & & & & & & & & -1 & & & & & & & & & & & \\
\hline WA & 28 & & & & & & & & & & & & & & & -1 & & & 46 & 75 & & & & & & & \\
\hline WA & 29 & & & & & & & & & & & & & & & 1 & & & & & & & & & & & \\
\hline WA & 30 & & & & & & & & & & & & & & & 5 & & & & & & & & & & & \\
\hline WA & 31 & & & & & & & & & & & & & & & 3 & & & & 0 & & & & & & & \\
\hline WA & 32 & & & & & & & & & & & & & & & 75 & & & 18 & 2 & & & & & & & \\
\hline WA & 33 & & & & & & & & & & & & & & & -1 & & & & 0 & & & & & & & \\
\hline WA & 34 & & & & & & & & & & & & & & & 1 & & & & & & & & & & & \\
\hline WA & 35 & & & & & & & & & & & & & & & 3 & & & & & & & & & & & \\
\hline WA & 36 & & & & & & & & & & & & & & & -1 & & & 15 & 0 & & & & & & & \\
\hline WA & 37 & & & & & & & & & & & & & & & 50 & & & & & & & & & & & \\
\hline WA & 38 & & & & & & & & & & & & & & & 2 & & & 30 & & & & & & & & \\
\hline WA & 39 & & & & & & & & & & & & & & & & -1 & & & & 338 & 655 & 295 & 20 & 325 & 642 & -1 \\
\hline WA & 40 & & & & & & & & & & & & & & & & -1 & & & & 4 & 100 & 0 & 0 & 0 & 0 & -1 \\
\hline WA & 41 & & & & & & & & & & & & & & & & -1 & & & & 0 & 1088 & 8200 & 370 & 300 & 1125 & -1 \\
\hline WA & 42 & & & & & & & & & & & & & & & & & & -1 & -1 & 90 & 85 & 26 & 29 & 18 & 6 & -1 \\
\hline WA & 43 & & & & & & & & & & & & & & & & & & -1 & & 800 & 120 & 1200 & 800 & 3750 & 400 & -1 \\
\hline WA & 44 & & & & & & & & & & & & & & & & & & -1 & & 20 & 30 & 150 & 260 & 300 & 300 & -1 \\
\hline WA & 45 & & & & & & & & & & & & & & & & & & -1 & & 0 & 72 & 20 & 1 & 3 & 61 & -1 \\
\hline WA & 46 & & & & & & & & & & & & & & & & & & -1 & -1 & 706 & 2240 & 535 & 325 & 405 & 395 & -1 \\
\hline WA & 47 & & & & & & & & & & & & & & & & & & -1 & -1 & 804 & 430 & 822 & 375 & 770 & 800 & -1 \\
\hline WA & 48 & & & & & & & & & & & & & & & & & -1 & & -1 & 1500 & 12275 & 5860 & 1184 & 3355 & 920 & -1 \\
\hline
\end{tabular}

Appendix B - 6 


\begin{tabular}{|c|c|c|c|c|c|c|c|c|c|c|c|c|c|c|c|c|c|c|c|c|c|c|c|c|c|c|c|}
\hline State & EO\# & 1967 & 1978 & 1980 & 1982 & 1983 & 1984 & 1985 & 1986 & 1987 & 1988 & 1989 & 1990 & 1991 & 1992 & 1993 & 1994 & 1995 & 1996 & 1997 & 1998 & 1999 & 2000 & 2001 & 2002 & 2003 & 2004 \\
\hline WA & 49 & & & & & & & & & & & & & & & & & & -1 & & & 500 & 42 & 300 & 1127 & 255 & -1 \\
\hline WA & 50 & & & & & & & & & & & & & & & & & & -1 & & 53 & 104 & 25 & 10 & 12 & 6 & -1 \\
\hline WA & 51 & & & & & & & & & & & & & & & & & & & -1 & 39 & 374 & 85 & 250 & 487 & 565 & -1 \\
\hline WA & 52 & & & & & & & & & & & & & & & & & & & 4 & 13 & 11 & 0 & 25 & 30 & 30 & -1 \\
\hline WA & 53 & & & & & & & & & & & & & & & & & & & -1 & 91 & 1038 & 136 & 22 & 27 & 402 & -1 \\
\hline WA & 54 & & & & & & & & & & & & & & & 9 & & & & & & & & & & & \\
\hline WA & 55 & & & & & & & & & & & & & & & 1 & & & & & & & & & & & \\
\hline WA & 56 & & & & & & & & & & & & & & & 3 & & & & 0 & & & & & & & \\
\hline WA & 57 & & & & & & & & & & & & & & & 1 & & & 39 & 0 & & & & & & & \\
\hline WA & 58 & & & & & & & & & & & & & & & 100 & & & 98 & 15 & & & & & & & \\
\hline WA & 59 & & & & & & & & & & & & & & & 1 & & & 9 & & & & & & & & \\
\hline WA & 60 & & & & & & & & & & & & & & & 3 & & & & & & & & & & & \\
\hline WA & 61 & & & & & & & & & & & & & & & 3 & & & 10 & 1 & & & & & & & \\
\hline WA & 62 & & & & & & & & & & & & & & & & & & 111 & 0 & & & & & & & \\
\hline WA & 63 & & & & & & & & & & & & & & & & & & 76 & & & & & & & & \\
\hline WA & 64 & & & & & & & & & & & & & & & & & -1 & & & & & & & & & \\
\hline WA & 65 & & & & & & & & & & & & & & & & & & & 7 & & & & & & & \\
\hline WA & 66 & & & & & & & & & & & & & & & & & & & & 429 & 100 & 100 & 200 & 200 & 400 & -1 \\
\hline WA & 67 & & & & & & & & & & & & & & & & & & & & & 1500 & & & & & \\
\hline WA & 68 & & & & & & & & & & & & & & & & & & & & & 1500 & & & & & \\
\hline WA & Trai & ing are & ea 11 & & & & & & & & & & & & & & & & & & & & & & & & -1 \\
\hline
\end{tabular}


APPENDIX C. HoWELlia AQUATILIS BIBLIOGRAPHY 


\section{HoWELLIA AQUATILIS BIBLIOGRAPHY}

Brunsfeld, S.J. and C.T. Baldwin. 1998.

Howellia aquatilis genetics: not so boring after all. In: Forum on Research and Management of Howellia aquatilis. Turnbull National Wildlife Refuge, Cheney, WA. March 24-25.

Bursick, R.J. 1995. Update: report on the conservation status of Howellia aquatilis in Idaho. Unpublished report. Idaho Department of Fish and Game, Boise. 8 pp.

Clegg, M. and A. Lombardi. 2000. Status report for water howellia (Howellia aquatilis) on Fort Lewis, WA. Report to the Land Condition Trend Analysis Program, Fort Lewis, WA. Environment and Engineering Inc., Norfolk, VA. 19 pp.

Davis, L. 2004. Flathead National Forest, FY05 - year report of annual monitoring requirements - annual monitoring of water howellia occurrences. Unpublished report. Flathead National Forest, MT.

Gamon, J. 1999. Inventory management plan for water howellia (Howellia aquatilis) on Fort Lewis. Final Reports. Washington Natural Heritage Program, WA Department of Natural Resources in coordination with The Nature Conservancy of Washington.

Gamon, J. 1998. Endangered species management plan for water howellia. Washington Natural Heritage Program, Department of Natural Resources.

Gamon, J. 1995. Report on the status in Washington of Howellia aquatilis A. Gray. Unpublished report. Washington Natural Heritage Program, Olympia. 32 pp.

Gamon, J. 1992. Report on the status in Washington of Howellia aquatilis A. Gray. Unpublished report. Washington Natural Heritage Program, Olympia. 46 pp.

Gamon, J. and T. Rush. 1998. Definition of potential habitat and a monitoring plan for water howellia (Howellia aquatilis) on Fort Lewis. Washington Natural Heritage Program, WA Department of Natural Resources in coordination with The Nature Conservancy of Washington.

Gilbert, R. 2002. Field report for water howellia surveys on Fort Lewis, WA. Report to the Land Condition Trend Analysis Program, Fort Lewis, WA. Environment and Engineering Inc., Norfolk, VA. 17 pp.

Gilbert, R. 2001. Status report for water howellia (Howellia aquatilis) on Fort Lewis, WA. Report to the Land Condition Trend Analysis Program, Fort Lewis, WA. Environment and Engineering Inc., Norfolk, VA. 9 pp.

Gilbert, R. and A. Lombardi. 1999. Status report for water howellia (Howellia aquatilis) on Fort Lewis, WA. Report to the Land Condition Trend Analysis Program, Fort Lewis, WA. Environment and Engineering Inc., Norfolk, VA. 25 pp.

Griggs, F.T. and J.E. Dibble. 1979. Status report, Howellia aquatilis A. Gray. for the Mendocino National Forest. Unpublished report. Mendocino National Forest, CA. 12 pp.

Isle, D.W. 1997. Rediscovery of water howellia for California. Fremontia 25(3): 29-32.

Jokerst, J.D. 1980. Status report, Howellia aquatilis A. Gray. for the Mendocino National Forest. Unpublished report. California State University, Chico. 18 pp.

Lesica, P. 1997. Spread of Phalaris arundinacea adversely impacts the endangered plant Howellia aquatilis. Great Basin Naturalist 57(4): 366-368.

Lesica, P. 1996. Monitoring Howellia aquatilis at Swan River Oxbow Preserve; 1994 Final Report. Report to The Nature Conservancy, Montana Field Office, Helena, MT. 6 pp. 
Lesica, P. 1995. Monitoring Howellia aquatilis at Swan River Oxbow Preserve; 1995 Progress Report. Report to The Nature Conservancy, Montana Field Office, Helena, MT. 4 pp.

Lesica, P. 1994. Monitoring Howellia aquatilis at Swan River Oxbow Preserve; 1994 Progress

Report. Report to The Nature Conservancy, Montana Field Office, Helena, MT. 5 pp.

Lesica, P. 1994. Monitoring Howellia aquatilis at Swan River Oxbow Preserve; 1993 Progress

Report. Report to The Nature Conservancy, Montana Field Office, Helena, MT. 4 pp.

Lesica, P. 1992. Autecology of the endangered plant Howellia aquatilis; implications for management and reserve design. Ecological Applications 2(4): 411-421.

Lesica, P. 1991. Monitoring Howellia aquatilis and Phalaris arundinacea at Swan River Oxbow Preserve; Progress Report. Unpublished report to The Nature Conservancy. $7 \mathrm{pp}$.

Lesica, P. 1990. Habitat requirements, germination behavior and seed bank dynamics of Howellia aquatilis in the Swan Valley, MT. Unpublished report to the USDA Forest Service, Flathead National Forest, MT. Conservation Biology Research, Missoula, MT. 44 pp. + appendices.

Lesica, P., R.F. Leary, F.W. Allendorf and D.E. Bilderback. 1988. Lack of genetic diversity within and among populations of an endangered plant, Howellia aquatilis. Conservation Biology 2(3): 275-282.

Lichthardt, J. and K. Gray. 2005. Monitoring of Howellia aquatilis (water howellia) and its habitat at the Harvard-Palouse River Flood Plain Site, Idaho: Fifth-year results. Idaho Department of Fish and Game, Idaho Conservation Data Center, Boise, ID. 10 pp. + appendices.

Lichthardt, J. and K. Gray. 2003. Monitoring of Howellia aquatilis (water howellia) and its habitat at the Harvard-Palouse River Flood Plain Site, Idaho: Fourth-year results. Idaho
Department of Fish and Game, Idaho Conservation Data Center, Boise, ID. 8 pp. + appendices.

Lichthardt, J. and K. Gray. 2001. Monitoring of Howellia aquatilis (water howellia) and its habitat at the Harvard-Palouse River Flood Plain Site, Idaho: Third-year results. Idaho Department of Fish and Game, Idaho Conservation Data Center, Boise, ID. 8 pp. + appendices.

Lichthardt, J. and R. Moseley. 2000. Ecological assessment of Howellia aquatilis habitat at the Harvard-Palouse River flood plain site. Boise, ID. Unpublished report. Prepared for the Idaho Department of Parks and Recreation by the Idaho Department of Fish and Game, Idaho Conservation Data Center. 14 pp. + appendices.

Mantas, M. 2002. Status of water howellia (Howellia aquatilis) and reed canarygrass (Phalaris arundinacea) in water howellia ponds: 1998-2001. Flathead National Forest, MT.

Mantas, M. 2000. Status of water howellia (Howellia aquatilis) and reed canarygrass (Phalaris arundinacea) in water howellia ponds: 1998 and 1999. Swan Valley, MT; monitoring report. Flathead National Forest, MT.

Mantas, M. 1998. Historical vs. current conditions of upland forests surrounding Howellia aquatilis habitats in the Swan Valley, MT. In: Forum on Research and Management of Howellia aquatilis. Turnbull National Wildlife Refuge, Cheney, WA. March 24-25.

McCarten, N. and R. Bittman. 1998. Water chemistry, nutrient cycling, productivity and environmental factors affecting plant community structure in Howellia aquatilis ponds. In: Forum on Research and Management of Howellia aquatilis. Turnbull National Wildlife Refuge, Cheney, WA. March 24-25. 11 pp.

McCune, B. 1982. Noteworthy collections, Montana: Howellia aquatilis. Madrono 29:123124. 
Reeves, D.M. 2001. Hydrologic controls on the survival of water howellia (Howellia aquatilis) and implications of land management, Swan Valley, MT. M.S. Thesis, The University of Montana, Missoula. 71 pp. + appendices.

Rice, D.J. 1990. An application of restoration ecology to the management of an endangered plant, Howellia aquatilis. M.S. thesis, Washington State University, Pullman. 85 pp.

Rice, D.J. 1989. Short-term protection of Howellia aquatilis: East Pond study area, Dishman Hills Natural Resource Conservation Area, Spokane, WA. Report to Department of Natural Resources. 13 pp.

Roe, L.S. and J.S. Shelly. 1992. Update to the status review of Howellia aquatilis: field surveys, monitoring studies and transplant experiments. Report to the USDA Forest Service, Flathead National Forest. Montana Natural Heritage Program, Helena, MT. 51 pp.

Schassberger, L.A. and J.S. Shelly. 1991. Update to the status review of Howellia aquatilis: field surveys, monitoring studies and transplant experiments. Report to the USDA Forest Service, Flathead National Forest. Montana Natural Heritage Program, Helena, MT. 57 pp.

Shapley, M. 1998. Field chemistry and basin geomorphology of Montana's Howellia aquatilis ponds (Abstract). In: Forum on Research and Management of Howellia aquatilis. Turnbull National Wildlife Refuge, Cheney, WA. March 24-25.

Shapley, M. 1998. Preliminary evaluation of basin morphometry and field chemistry of Montana's Howellia aquatilis ponds. Unpublished report to the Flathead National Forest, Kalispell, MT and U.S. Fish and Wildlife Service, Denver, CO. Montana Natural Heritage Program, Helena, MT. 7 pp. + figures and tables.

Shapley, M.D. and P. Lesica. 1997. Howellia aquatilis (water howellia) ponds of the Swan Valley: Conceptual hydrologic models and ecological implications. Report to the U.S. Fish and Wildlife Service, Denver, CO. Montana Natural Heritage Program, Helena, MT and Conservation Biology Research, Missoula, MT. $44 \mathrm{pp}$.

Shelly, J.S. 1998. Howellia aquatilis - ten years of monitoring, Swan Valley, MT. In: Forum on Research and Management of Howellia aquatilis. Turnbull National Wildlife Refuge, Cheney, WA. March 24-25.

Shelly, J.S. 1998. Translocation experiments, Swan Valley, MT. In: Forum on Research and Management of Howellia aquatilis. Turnbull National Wildlife Refuge, Cheney, WA. March 24-25.

Shelly, J.S. 1995. Eccentric aquatic (conservation of endangered Howellia aquatilis). American Horticulturist. 74: 11.

Shelly, J.S. 1995. Howellia aquatilis: Montana's first federally listed plant species. Kelseya, Newsletter of the Montana Native Plant Society.

Shelly, J.S. 1989. Addendum to the status review of Howellia aquatilis, U.S. Forest Service, Region 1, Flathead National Forest. Montana Natural Heritage Program, Helena, MT. 17 pp.

Shelly, J.S. 1988. Distribution and status of Howellia aquatilis A. Gray (Campanulaceae) in Lake and Missoula Counties, MT (Abstract). Proc. Mont. Acad. Sci. 48(12).

Shelly, J.S. 1988. Status review of Howellia aquatilis, U.S. Forest Service, Region 1, Flathead National Forest. Montana Natural Heritage Program, Helena, MT. 120 pp.

Shelly, J.S. and R. Moseley. 1988. Report on the conservation status of Howellia aquatilis, a candidate threatened species. Montana Natural Heritage Program, Helena, MT. 74 pp. + appendices.

USDA Forest Service. 1997. Conservation strategy for Howellia aquatilis A. Gray (second 
edition). USDA Forest Service, Flathead National Forest. 24 pp.

USDA Forest Service. 1994. Conservation strategy for Howellia aquatilis A. Gray. USDA Forest Service, Flathead National Forest. 26 pp.

U.S. Fish and Wildlife Service. 1996. Water howellia (Howellia aquatilis) recovery plan, public and agency review draft. Report to the U.S. Fish and Wildlife Service. 52 pp.

U.S. Fish and Wildlife Service. 1996. Biological opinion on amendment 20 to the Flathead National Forest plan. Montana Field Office, Helena. 13 pp.

U.S. Fish and Wildlife Service. 1994. Endangered and threatened wildlife and plants; the plant water howellia (Howellia aquatilis), determined to be a threatened species. Federal Register 59(134): 35860-35864.

U.S. Fish and Wildlife Service. 1993.

Endangered and threatened wildlife and plants;
Proposed listing of water howellia (Howellia aquatilis) as threatened. Federal Register 58(72): 19795-19800.

Woessner, W.W. and B. Heidel. 1999 and 2000. Preserving the function of unique wetlands critical to the survival of water howellia in the Swan Valley, MT. Progress Reports to the Montana Department of Environmental Quality, Helena, MT. Department of Geology, University of Montana, Missoula and the Montana Natural Heritage Program.

Wolfold, L. 2004. Water howellia (Howellia aquatilis) monitoring on Fort Lewis Military Reservation field report, 2004. Report to the Land Condition Trend Analysis Program, Fort Lewis, WA. Environment and Engineering Inc., Norfolk, VA. 22 pp.

Wolfold, L. 2003. Water howellia monitoring on Fort Lewis, 2003. Report to the Land Condition Trend Analysis Program, Fort Lewis, WA. Environment and Engineering Inc., Norfolk, VA. 17 pp. 


\section{APPENDiX D. Global/State RANK DEFinitions}




\section{HERITAGE PROGRAM RANKS}

The international network of Natural Heritage Programs employs a standardized ranking system to denote global (range-wide) and state status. Species are assigned numeric ranks ranging from 1 to 5, reflecting the relative degree to which they are "at-risk". Rank definitions are given below. A number of factors are considered in assigning ranks - the number, size and distribution of known "occurrences" or populations, population trends (if known), habitat sensitivity, and threat. Factors in a species' life history that make it especially vulnerable are also considered (e.g., dependence on a specific pollinator).

GLOBAL RANK DEFINITIONS (NatureServe 2003)

G1 Critically imperiled because of extreme rarity and/or other factors making it highly vulnerable to extinction

G2 Imperiled because of rarity and/or other factors making it vulnerable to extinction

G3 Vulnerable because of rarity or restricted range and/or other factors, even though it may be abundant at some of its locations

G4 Apparently secure, though it may be quite rare in parts of its range, especially at the periphery

G5 Demonstrably secure, though it may be quite rare in parts of its range, especially at the periphery

T1-5 Infraspecific Taxon (trinomial) - The status of infraspecific taxa (subspecies or varieties) are indicated by a "T-rank" following the species' global rank

\section{STATE RANK DEFINITIONS}

S1 At high risk because of extremely limited and potentially declining numbers, extent and/or habitat, making it highly vulnerable to extirpation in the state

S2 At risk because of very limited and potentially declining numbers, extent and/or habitat, making it vulnerable to extirpation in the state

S3 Potentially at risk because of limited and potentially declining numbers, extent and/or habitat, even though it may be abundant in some areas

S4 Uncommon but not rare (although it may be rare in parts of its range), and usually widespread. Apparently not vulnerable in most of its range, but possibly cause for long-term concern

S5 Common, widespread, and abundant (although it may be rare in parts of its range). Not vulnerable in most of its range

\section{COMBINATION RANKS}

G\#G\# or S\#S\# Range Rank-A numeric range rank (e.g., G2G3) used to indicate uncertainty about the exact status of a taxon

\section{QUALIFIERS}

NR

Not ranked

Q Questionable taxonomy that may reduce conservation priority-

Distinctiveness of this entity as a taxon at the current level is questionable; resolution of this uncertainty may result in change from a species to a subspecies or hybrid, or inclusion of this taxon in another taxon, with the resulting taxon having a lower-priority (numerically higher) conservation status rank 
$\mathrm{X}$

$\mathrm{H}$

$\mathrm{U}$

HYB

?

$\mathrm{C}$

A

Z

$\mathrm{P}$

$\mathrm{R}$

SYN

$*$

B

$\mathrm{N}$

Presumed Extinct-Species believed to be extinct throughout its range. Not located despite intensive searches of historical sites and other appropriate habitat, and virtually no likelihood that it will be rediscovered

Possibly Extinct-Species known from only historical occurrences, but may never-theless still be extant; further searching needed

Unrankable - Species currently unrankable due to lack of information or due to substantially conflicting information about status or trends

Hybrid-Entity not ranked because it represents an interspecific hybrid and not a species

Inexact Numeric Rank-Denotes inexact numeric rank

Captive or Cultivated Only-Species at present is extant only in captivity or cultivation, or as a reintroduced population not yet established

Accidental-Species is accidental or casual in Montana, in other words, infrequent and outside usual range. Includes species (usually birds or butterflies) recorded once or only a few times at a location. A few of these species may have bred on the one or two occasions they were recorded

Zero Occurrences-Species is present but lacking practical conservation concern in Montana because there are no definable occurrences, although the taxon is native and appears regularly in Montana

Potential—Potential that species occurs in Montana but no extant or historic occurrences are accepted

Reported-Species reported in Montana but without a basis for either accepting or rejecting the report, or the report not yet reviewed locally. Some of these are very recent discoveries for which the program has not yet received first-hand information; others are old, obscure reports

Synonym - Species reported as occurring in Montana, but the Montana Natural Heritage Program does not recognize the taxon; therefore the species is not assigned a rank

A rank has been assigned and is under review. Contact the Montana Natural Heritage Program for assigned rank

Breeding-Rank refers to the breeding population of the species in Montana Nonbreeding - Rank refers to the non-breeding population of the species in Montana 
APPENDIX E. ELEMENT OCCURRENCE RANK DEFINITIONS 


\section{ELEMENT OCCURRENCE RANK DEFINITIONS}

A - Excellent estimated viability/ecological integrity

A? - Possibly excellent estimated viability/ecological integrity

$\mathrm{AB}$ - Excellent or good estimated viability/ecological integrity

AC - Excellent, good, or fair estimated viability/ecological integrity

B - Good estimated viability/ecological integrity

B? - Possibly good estimated viability/ecological integrity

BC - Good or fair estimated viability/ecological integrity

BD - Good, fair, or poor estimated viability/ecological integrity

C - Fair estimated viability/ecological integrity

C? - Possibly fair estimated viability/ecological integrity

CD - Fair or poor estimated viability/ecological integrity

D - Poor estimated viability/ecological integrity

D? - Possibly poor estimated viability/ecological integrity

E - Verified extant (viability/ecological integrity not assessed)

F - Failed to find

F? - Possibly failed to find

$\mathrm{H}$ - Historical

H? - Possibly historical

$X$ - Extirpated

$\mathrm{X}$ ? - Possibly extirpated

U - Unrankable

NR - Not ranked 